\title{
¿QUIENES ERAN LOS ACCIONISTAS DEL BANCO DE ESPAÑA? *
}

\author{
RICARDO ROBLEDO \\ Universidad Autónoma de Barcelona
}

«Reorganizose el banco después de una liquidación general en 1829 y tomó el nombre de San Fernando que al través de mil vicisitudes políticas y comerciales hoy vive y prospera para bien de sus accionistas más que en utilidad común con el título de Banco de España."

(Manuel Colmeiro, Historia de la Economia Politica, 1863.)

Diversas investigaciones sobre el Banco de España nos han permitido conocer la evolución de sus activos y pasivos, las vicisitudes de su vinculación con el Tesoro, su expansión por provincias o la favorable cotización de sus acciones, pero no sabemos quiénes eran los que se veían principalmente beneficiados por esto último, es decir, nos es prácticamente desconocido el nombre de los mayores accionistas, por más que haya referencias como la que encabeza este artículo, de lo bien que les iba a tales accionistas; otros contemporáneos se atrevieron a recargar aún más las tintas o a cuantificar suculentos beneficios '.

Posiblemente la fuerte vinculación del Banco con el sector público (desde ser "prestamista del Tesoro" hasta «Tesorero del Estado» ${ }^{2}$ ) y la facultad que tenía el Gobierno para nombrar sus primeras autoridades han facilitado el anonimato sobre sus accionistas como si la situación actual del Banco después de la nacionalización de 1962 correspondiera a la de un siglo atrás. A diferencia de los textos de contemporáneos de fines de siglo xIx y principios del xx, a veces hemos olvidado que el Banco de España era entonces una entidad privada que con sus actuaciones o inhibiciones solamente pre-

\footnotetext{
* Comunicación presentada al XII Simposio de Análisis Económico, Barcelona, 1987. Es un apartado de la investigación, inédita, Notas sobre el papel de las grandes fortunas en la España Contemporánea, Informe Banco de España, 1985.

${ }^{1}$ Diversos testimonios aparecen recogidos por G. Tortella $(1970 \mathrm{a})$, p. 30. Este autor me indicó la existencia del panfleto de Leoncio Rodríguez (1902). Según Azcárate, el poseedor de 2.000 acciones en 1870 habría multiplicado por más de siete su capital inicial en 1890; citado en R. Anes (1974), p. 160.

Servicio que se interpretaba como el más propio de un Banco Nacional y el que permitia «el estado próspero de la Hacienda Pública» (sic). Memoria (1883), p. 15.
} 
tendía proporcionar el máximo dividendo a unos accionistas de quienes ignoramos casi todo. Un estudio que indirectamente daba noticia sobre ellos es el de D. Mateo del Peral, al identificar a diversas autoridades económicas durante la Restauración ${ }^{3}$. Pero en general me parece que predomina la incertidumbre y seguro que a más de uno puede sorprenderle el que las Hijas de la Caridad de San Vicente de Paúl fueran uno de los grandes accionistas en $1911^{4}$.

\section{Número de accionistas y representación regional}

En el cuadro 1 se expone la evolución del número de accionistas y el peso que tenían los poseedores de 50 o más acciones. Desde 1881 nos referimos a la Central de Madrid, que hasta el segundo decenio de este siglo controlaba la mayoría de capital, aunque desde 1892 hubiera perdido la hegemonía en cuanto al número de accionistas. En ello había influido la transferencia a sucursales, cada vez más numerosas, para domiciliación de acciones y la existencia de nuevos titulares después de la compensación en acciones (29.500) que diversos Bancos recibieron con motivo del Decreto de Echegaray.

Ante el predominio de Madrid en el capital del Banco poco quedaba para cada una de las sucursales, que en número de 60 , hacia 1912 , se extendían por las regiones españolas. Destaquemos, sin embargo, la representación del País Vasco y Navarra (con el 14 por 100 de accionistas y acciones), lo que añadido a la participación de Galicia y Asturias ( 9 por 100) supondría que las tres cuartas partes del capital se concentraba a principios del siglo $\mathrm{xx}$ en Madrid y regiones del Norte. Uno de los panfletos más virulentos que se han escrito contra el Banco de España atribuía la fuerte representación en las provincias vascas al hecho de que allí residian preferentemente «el jesuitismo y sus auxiliares» ${ }^{5}$.

${ }^{3}$ El trabajo de D. Mateo del Peral (1974) ha sido de gran utilidad en esta investigación.

- La fuente principal que he estudiado es la lista de ulos señores accionistas que tienen derecho de asistencia a la Junta General», celebrada generalmente en la primera quincena del mes de marzo. Tenían tal derecho los poseedores de 50 o más acciones, salvo en 1852 (Banco Nuevo de San Fernando), donde el mínimo era de 40 acciones. Se trata de listas publicadas, excepto la de 1852, primero como edición independiente de las Memorias del Banco y, más adelante, como apéndice de las mismas. He dispuesto de estas listas a partir de $1861 \mathrm{y}$, desde entonces, he establecido cortes decenales hasta 1931 para la identificación de los 50 grandes accionistas que figuran en el Apéndice.

3 L. Rodríguez (1902), p. 19. Es una de las obsesiones de este autor, pero no aporta argumentos convincentes. En marzo de 1875 pidieron la integración únicamente los bancos de las provincias vascas - -según él, «los de CASA»-, pero, como se sabe, el de Bilbao fue de los que se resistió a tal integración. Sin embargo, como veremos, la representación eclesiástica en el Banco de España no era despreciable. 


\section{CUADRO 1}

Representación de mayores accionistas (1852-1931)

\begin{tabular}{|c|c|c|c|c|c|c|}
\hline \multirow[b]{2}{*}{$A \tilde{n} o s$} & \multicolumn{2}{|c|}{ TOTAL ACCIONISTAS } & \multicolumn{2}{|c|}{$\begin{array}{l}\text { MAYORES ACCIONISTAS } \\
(>50 \text { acciones })\end{array}$} & \multirow[b]{2}{*}{$\begin{array}{l}3 / 1 \\
(\%)\end{array}$} & \multirow[b]{2}{*}{$\begin{array}{l}4 / 2 \\
(\%)\end{array}$} \\
\hline & $\begin{array}{l}\text { Número } \\
\text { (1) }\end{array}$ & $\begin{array}{l}\text { Acciones } \\
\text { (2) }\end{array}$ & $\underset{(3)}{\text { Número }}$ & $\begin{array}{l}\text { Acciones } \\
\text { (4) }\end{array}$ & & \\
\hline $\begin{array}{l}1852 \\
1861 \\
1871 \\
1881\end{array}$ & $\begin{array}{r}1700 \\
1732 \\
2246 \\
\text { (M) } 3692 \\
\text { (S) } 1431\end{array}$ & $\begin{array}{r}60.000 \\
60.000 \\
100.000 \\
160.635 \\
39.142\end{array}$ & $\begin{array}{l}378 \\
329 \\
520 \\
797\end{array}$ & $\begin{array}{r}40.500 \\
42.414 \\
73.092 \\
119.224\end{array}$ & $\begin{array}{l}22,2 \\
19,0 \\
23,2 \\
21,6\end{array}$ & $\begin{array}{l}67,5 \\
70,7 \\
73,1 \\
74,5\end{array}$ \\
\hline 1891 & $\begin{array}{l}\text { (M) } 4150 \\
\text { (S) } 3915\end{array}$ & $\begin{array}{l}194.141 \\
105.858\end{array}$ & 969 & 153.448 & 23,3 & 79,0 \\
\hline 1901 & $\begin{array}{l}\text { (M) } 4208 \\
\text { (S) } 5892\end{array}$ & $\begin{array}{l}174.747 \\
125.252\end{array}$ & 867 & 138.562 & 20,6 & 79,3 \\
\hline 1911 & $\begin{array}{r}\text { (M) } 4397 \\
\text { (S) } 8168\end{array}$ & $\begin{array}{l}153.923 \\
146.076\end{array}$ & 771 & 119.181 & 17,5 & 77,4 \\
\hline 1921 & $\begin{array}{r}\text { (M) } 4360 \\
\text { (S) } 9066\end{array}$ & $\begin{array}{l}142.976 \\
157.024\end{array}$ & 750 & 108.930 & 17,2 & 76,2 \\
\hline 1931 & $\begin{array}{l}\text { (M) } 4968 \\
\text { (S) } 10458\end{array}$ & $\begin{array}{l}160.917 \\
193.083\end{array}$ & 867 & 125.610 & 17,4 & 78,1 \\
\hline
\end{tabular}

$(M)=$ Madrid; $(S)=$ Sucursales.

Fuente: Elaboración según Memoria(s) del Banco de España, salvo para 1852 (Banco Nuevo de San Fernando), en Archivo del Banco, Secretaría, leg. 463. El número total de accionistas para 1852 es estimado a partir de E. Martínez (1922), p. 35.

Aunque no se pueda conceder toda fiabilidad a los datos que aparecen representados en el mapa 1 -pues varios de los que residían en provincias siguieron teniendo domiciliadas las acciones en la Central de Madrid-, no deja de sorprender que Cataluña figure en los últimos lugares por su participación en el capital del Banco, lo que sin duda facilitaba la animadversión que los hombres de negocios barceloneses mostraban con la actuación del Banco de España ${ }^{6}$.

- Véanse, más adelante, notas 28-29. Eso no quiere decir que dejaran de beneficiarse de otros negocios afines a los del Banco. Por poner un ejemplo, Barcelona figura a la cabeza de las provincias que suscribieron obligaciones del empréstito nacional «patriótico" de 1896; ténganse en cuenta también las principales actividades del Banco Hispano-Colonial. 


\section{MAPA 1 \\ Accionistas del Banco de España \\ 1912}

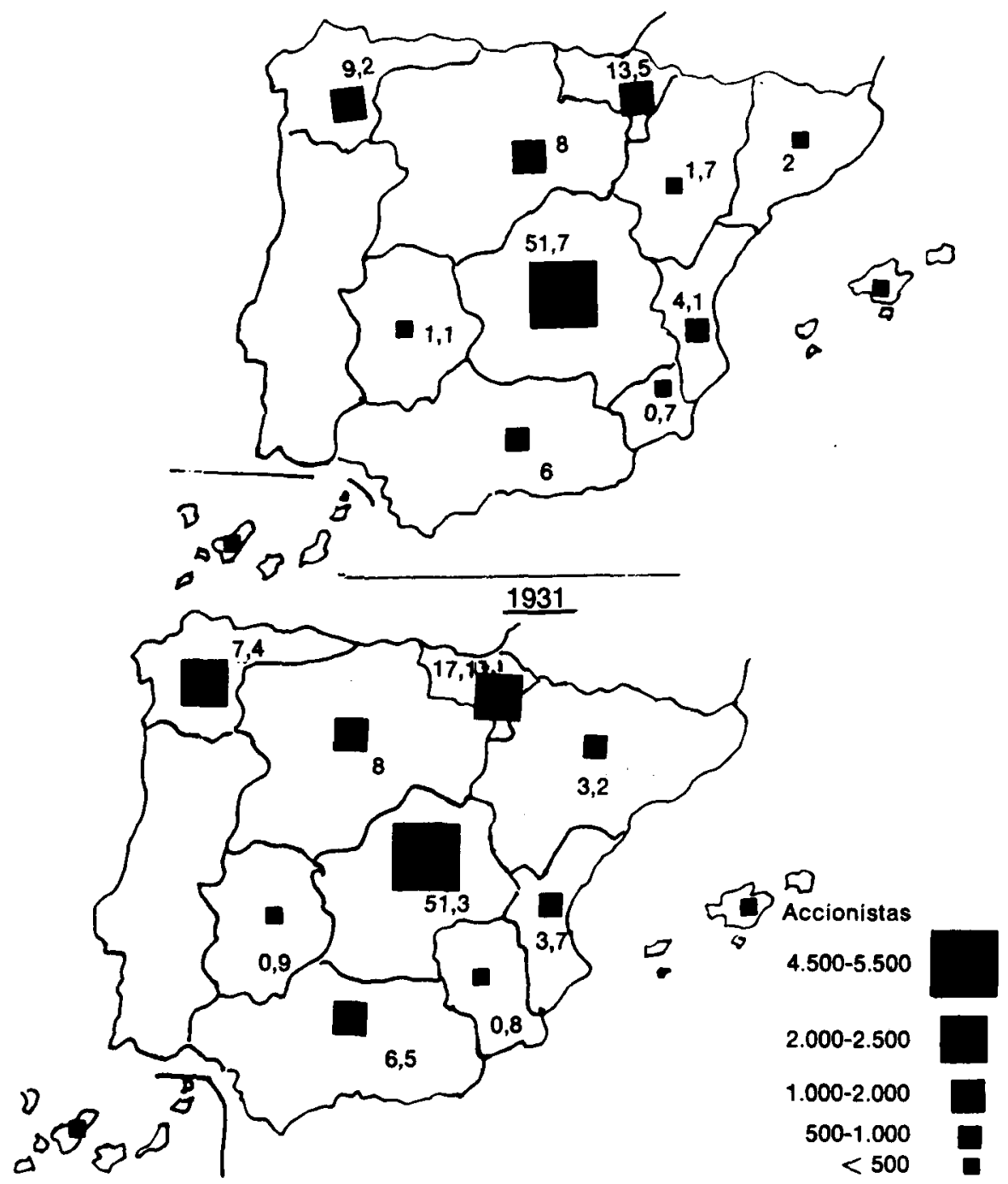

Fuentes: Elaboración a partir de J. Ceballos (1913) y Proyecto (1931). Las cifras que figuran para cada región corresponden, en 1912, al porcentaje de acciones y, en 1931, al porcentaje que representan los titulares de más de 50 acciones. 


\section{Los accionistas y los grandes terratenientes}

Dentro del total de accionistas conviene fijarse en el grupo de los que poseen por encima de 50 acciones, pues eran alrededor de una quinta parte y controlaban cerca del 70 por 100 o más del capital del Banco en Madrid. Uno de los pocos datos que acompaña (y no siempre) al nombre del accionista era el título de nobleza, y éste puede ser un punto de partida para la identificación de este grupo. Aunque la nobleza no era ya signo inequivoco de gran propiedad agraria, sabemos que para los antiguos títulos aún lo seguía siendo.

El número de nobles dentro del grupo de los grandes accionistas fue creciendo, desde un 4 por 100 en 1861 al 19 por 100 en 1931 (con un número de acciones que superaba siempre el promedio); pero las características de estos títulos - concretamente la fecha de su concesión (o de su rehabilitación, porque la antigüedad no siempre es el criterio determinante)diluye cualquier espejismo sobre la participación de la nobleza tradicional. He localizado cerca de 340 títulos distintos que figuraban como accionistas de 1861 a 1931. Casi dos tercios proceden de concesiones del siglo xIx, y a diferencia de lo que ocurre con la propiedad de la tierra se produce con frecuencia una relación inversa entre antigüedad de los títulos y números de acciones?. Son los ennoblecidos de la etapa isabelina o de la Restauración — por sus servicios políticos o militares- los que ocupan los primeros puestos. Incluso varios de los apellidos (Fernández Casariego, Goyeneche, Crooke...) que se adornan con títulos del siglo $\mathrm{xv}$, tales como Conde de Valencia, Marquesa de Zahara, Duque de Nájera, etc., aportan bastantes sospechas sobre matrimonios de antiguos aristócratas con representantes de la burguesía de los negocios o del comercio y, por tanto, el peso de los intereses agrarios - como herencia del Antiguo Régimen- ya no es tan claro.

Si en vez de fijarnos en la nobleza, antigua o advenediza, nos referimos a grandes terratenientes, la conexión con los accionistas es mucho más explícita. Según la información que ofrece la lista de mayores contribuyentes de 1854, al menos una cuarta parte de los 52 mayores terratenientes espanoles figuraban como accionistas del Banco. El Cuadro 2 da cuenta de esta relación veinticinco años después ${ }^{8}$.

Este cuadro podría ampliarse si en vez de tomar en consideración al medio centenar de grandes accionistas nos refiriéramos a los poseedores de

7 R. Robledo (1985), cuadros 11 y 12. Duque de Alba y Duque de Medinaceli no llegan a las 100 acciones. Para la antigüedad de los títulos he consultado Elenco (1981) y la Guia oficial (1977).

- La lista de contribuyentes, en Rosa Congost (1983), pp. 316 y ss. 
CUADRO 2

Relación entre grandes contribuyentes españoles por territorial $y$ grandes accionistas del Banco de España

\begin{tabular}{|c|c|c|c|c|}
\hline Terratenientes & $N \cdot$ orden & Provincias ** & Acciones & Años \\
\hline 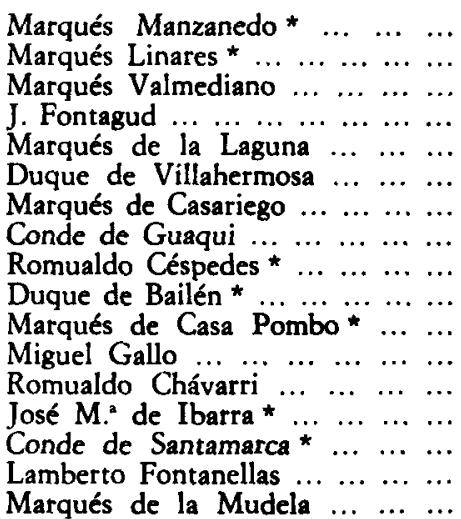 & $\begin{array}{r}4 \\
7 \\
18 \\
25 \\
27 \\
29 \\
46 \\
50 \\
67 \\
105 \\
135 \\
154 \\
215 \\
263 \\
264 \\
270 \\
310\end{array}$ & $\begin{array}{l}\text { Madrid } \\
\text { Madrid } \\
\text { Córdoba } \\
\text { Málaga } \\
\text { Jaén } \\
\text { Jaén } \\
\text { Córdoba } \\
\text { Toledo } \\
\text { Madrid } \\
\text { Madrid } \\
\text { Valladolid } \\
\text { Toledo } \\
\text { Madrid } \\
\text { Sevilla } \\
\text { Madrid } \\
\text { Barcelona } \\
\text { Toledo }\end{array}$ & $\begin{array}{r}290 \\
767 \\
295 \\
250 \\
1.250 \\
735 \\
750 \\
1.309 \\
500 \\
551 \\
518 \\
400 \\
396 \\
415 \\
540 \\
300 \\
883\end{array}$ & $\begin{array}{l}1871 \\
1871 \\
1891 \\
1852 \\
1861 \\
1901 \\
1871 \\
1871 \\
1881 \\
1891 \\
1901 \\
1871 \\
1881 \\
1881 \\
1891 \\
1861 \\
1881\end{array}$ \\
\hline
\end{tabular}

* El titular de las acciones es, por lo general, el consorte.

* Donde cada terrateniente satisface la mayor cuota por contribución territorial.

50 o más acciones. Del total de 315 grandes contribuyentes que aparecen en la lista de 1875 elaborada por Rosa Congost, al menos unos 60 tenían acciones en el Banco de España. Igualmente la vinculación se confirma con las listas provinciales de contribuyentes sin peso suficiente para figurar en la relación de 1875. Grandes accionistas del Banco como F. Lasala, G. Roiz de la Parra, Hijos de M. Agustín Heredia, J. Finat figuran como contribuyentes en Burgos, Santander, Almería y Segovia, respectivamente.

No parece que haya que sorprenderse porque el terrateniente o el propietario de inmuebles urbanos aparezca en los primeros lugares del accionariado del Banco de España. El rico español de mediados del siglo xIx, al igual que ocurría también en la industrializada Inglaterra ${ }^{9}$, lo era por ser propietario de tierras o casas, como confirman los inventarios post mortem que he consultado. Si para diversificar estos activos compran acciones del Banco no arriesgan demasiado: se trata de una inversión que compensa por su seguridad, liquidez y buenos dividendos.

Conviene precisar que el hecho de que los terratenientes aparezcan a la vez como accionistas no presupone, en principio, que el beneficio conseguido

\footnotetext{
- Rubinstein (1981).
} 
por la explotación directa o indirecta de la tierra estuviera en los orígenes de capital del Banco o formara parte del mercado secundario de compraventa de acciones que cada año movilizaba varias decenas de millones de pesetas. Las relaciones no se establecen en una sola dirección y no sería extraño que algunos de los beneficios conseguidos como accionistas pudieran invertirse en la compra de tierras, sobre todo si se tiene en cuenta un mercado tan dinámico como el formado por la desamortización y desvinculación.

Lo que sí sugiere nuestra investigación es que no puede encasillarse a la élite económica en industriales, banqueros, comerciantes o propietarios territoriales en compartimentos estancos, algo que la creación de sociedades bancarias de 1856-68 o las listas de compradores de la desamortización se encargan de desmentir. Ciertamente, la impresión que domina en el tema de los orígenes del capital bancario es excesivamente restrictiva respecto a la participación del sector agrario. Ahora bien, si para descalificar tal ahorro han bastado los nombres de los fundadores de bancos, la conexión establecida entre terratenientes y accionistas de un Banco que superaba en activos a todos los demás juntos, debería ayudar, cuando menos, a matizar tales afirmaciones.

\section{La pertinaz supervivencia de un grupo de accionistas}

El poder de concentración de los 50 grandes accionistas era bastante elevado, pues representando cuando mucho un 3 por 100 en el total de accionistas poseen de un quinto a un tercio de las acciones domiciliadas en Madrid. De entre éstos, destacan los poseedores de más de 1.000 acciones (cuadro 3), varios de ellos con papeles destacados en la revolución liberal o en la Restauración. Pero tanto el peso como la permanencia en el tiempo se incrementan lógicamente si nos referimos a grupos familiares. Se contrarrestan así los efectos del reparto de acciones entre los herederos al tiempo que se percibe la práctica de estrategias matrimoniales que refuerzan el dominio de esta «oligarquía financiera».

Para la identificación de estas familias he analizado con más detalle a los principales accionistas, una veintena de ellos, iniciando la serie en 1852, con el antecesor del Banco de España. Al finalizar el recuento en 1931, la hipotética supervivencia de los accionistas debe plantearse en términos de más de una generación, acudiendo a la información que proporcionan las listas para la identificación de los sucesores (referencias a viudas, hijos, y, sobre todo, la posesión del mismo título nobiliario) ${ }^{\mathbf{1 0}}$.

10 Por ejemplo, en el caso de J. M. Collado hemos continuado la serie con la Marquesa de Portugalete (Collado y Echagüe) y Vizconde de Jarafe (F. Collado), pero no hemos 


\section{CUADRO 3}

Titulares de 1.000 o más acciones

\begin{tabular}{|c|c|c|c|c|c|}
\hline \multicolumn{2}{|l|}{1852} & \multicolumn{2}{|l|}{1861} & \multicolumn{2}{|l|}{1871} \\
\hline $\begin{array}{l}\text { J. M. Collado } \\
\text { F. Lasala Collado }\end{array}$ & $\begin{array}{l}\left(10^{\circ}\right) \\
\left(20^{\circ}\right)\end{array}$ & $\begin{array}{l}\text { J. M. Collado } \\
\text { F. Lasala Collado }\end{array}$ & $\begin{array}{l}\left(2 \circ^{\circ}\right) \\
\left(3 .^{\circ}\right)\end{array}$ & $\begin{array}{l}\text { Conde Guaqui (Goye- } \\
\text { neche) } \\
\text { Campos y Martínez } \\
\text { A. González } \\
\text { D. Collado } \\
\text { F. Collado }\end{array}$ & $\begin{array}{l}\left(2.0^{\circ}\right) \\
\left(3.0^{\circ}\right) \\
\left(40^{\circ}\right) \\
\left(50^{\circ}\right) \\
\left(6.0^{\circ}\right)\end{array}$ \\
\hline \multicolumn{2}{|l|}{1881} & \multicolumn{2}{|l|}{1891} & \multicolumn{2}{|l|}{1901} \\
\hline $\begin{array}{l}\text { Hermanos Urquijo } \\
\text { D. F. Montañés } \\
\text { M. Esteban } \\
\text { P. Bermejillo } \\
\text { Miqueletorena } \\
\text { D. Collado } \\
\text { Elduayen }\end{array}$ & $\begin{array}{l}\left(20^{\circ}\right) \\
\left(30^{\circ}\right) \\
\left(40^{\circ}\right) \\
\left(50^{\circ}\right) \\
\left(60^{\circ}\right) \\
\left(70^{\circ}\right) \\
\left(90^{\circ}\right)\end{array}$ & $\begin{array}{l}\text { Plà y Monge } \\
\text { Miqueletorena } \\
\text { Díez y Bustamante } \\
\text { Desmaisieres y Sevi- } \\
\quad \text { llano } \\
\text { P. Escolar } \\
\text { M. Berthon } \\
\text { M. Vallejo } \\
\text { J. Curiel } \\
\text { Elduayen }\end{array}$ & $\begin{array}{l}\left(2.0^{\circ}\right) \\
\left(3.0^{\circ}\right) \\
\left(5.0^{\circ}\right) \\
\left(7.0^{\circ}\right) \\
\left(8.0^{\circ}\right) \\
\left(90^{\circ}\right) \\
\left(100^{\circ}\right) \\
\left(110^{\circ}\right) \\
\left(12 \circ^{\circ}\right)\end{array}$ & $\begin{array}{l}\text { Miqueletorena } \\
\text { Díez y Bustamante } \\
\text { Desmaisieres y Sevi- } \\
\quad \text { llano } \\
\text { Marqués Perinat } \\
\text { Elduayen }\end{array}$ & $\begin{array}{l}\left(3 .^{\circ}\right) \\
\left(4 .^{\circ}\right) \\
\left(6.0^{\circ}\right) \\
\left(7 .^{\circ}\right) \\
\left(8 .^{\circ}\right)\end{array}$ \\
\hline \multicolumn{2}{|l|}{1911} & \multicolumn{2}{|l|}{1921} & \multicolumn{2}{|l|}{1931} \\
\hline $\begin{array}{l}\text { Miqueletorena } \\
\text { Díez y Bustamante } \\
\text { Desmaisieres y Sevi- } \\
\text { llano } \\
\text { M. D. Romero } \\
\text { M.: C. Goyeneche } \\
\text { M.: J. Goyeneche }\end{array}$ & $\begin{array}{l}\left(3.0^{\circ}\right) \\
\left(5.0^{\circ}\right) \\
\left(6.0^{\circ}\right) \\
\left(70^{\circ}\right) \\
\left(8.0^{\circ}\right) \\
\left(90^{\circ}\right)\end{array}$ & $\begin{array}{l}\text { M: J. Goyeneche } \\
\text { Plà y Peñalver } \\
\text { Goyeneche } \\
\text { Miqueletorena } \\
\text { Desmaisieres y Sevi- } \\
\text { llano }\end{array}$ & $\begin{array}{l}\left(3.0^{\circ}\right) \\
\left(4 . \circ^{\circ}\right) \\
\left(60^{\circ}\right) \\
\left(7.0^{\circ}\right) \\
\left(8.0^{\circ}\right)\end{array}$ & $\begin{array}{l}\text { Plà y Peñalver } \\
\text { Miqueletorena } \\
\text { Collado } \\
\text { Mazarredo }\end{array}$ & $\begin{array}{l}\left(30^{\circ}\right) \\
\left(40^{\circ}\right) \\
\left(80^{\circ}\right) \\
\left(90^{\circ}\right)\end{array}$ \\
\hline
\end{tabular}

Nota: Entre paréntesis figura el número de orden en lista de accionistas (se excluyen Fundaciones o similares).

incluido al Marqués de Portugalete, E. Carondelet, que era otro gran accionista, o a F. Lasala Collado. El título de Marqués de Valdeterrazo permite seguir a los sucesores de Antonio González, presidente del Consejo de Ministros, y la Marquesa de Fuentes de Duero o Condesa de Vega del Pozo (Desamaisieres y Sevillano) dan seguridad para hablar de los sucesores de J. Sevillano. En todo caso, las cifras del cuadro 4 pecan por defecto. Un estudio informatizado (y con mejor conocimiento de los enlaces matrimoniales) ampliaría nuestras estimaciones, sobre todo si continuáramos las pesquisas por las sucursales. El interrogante que acompaña a algún accionista en dicho cuadro indica que no dispongo de información para asegurar que pertenece a la misma familia. 


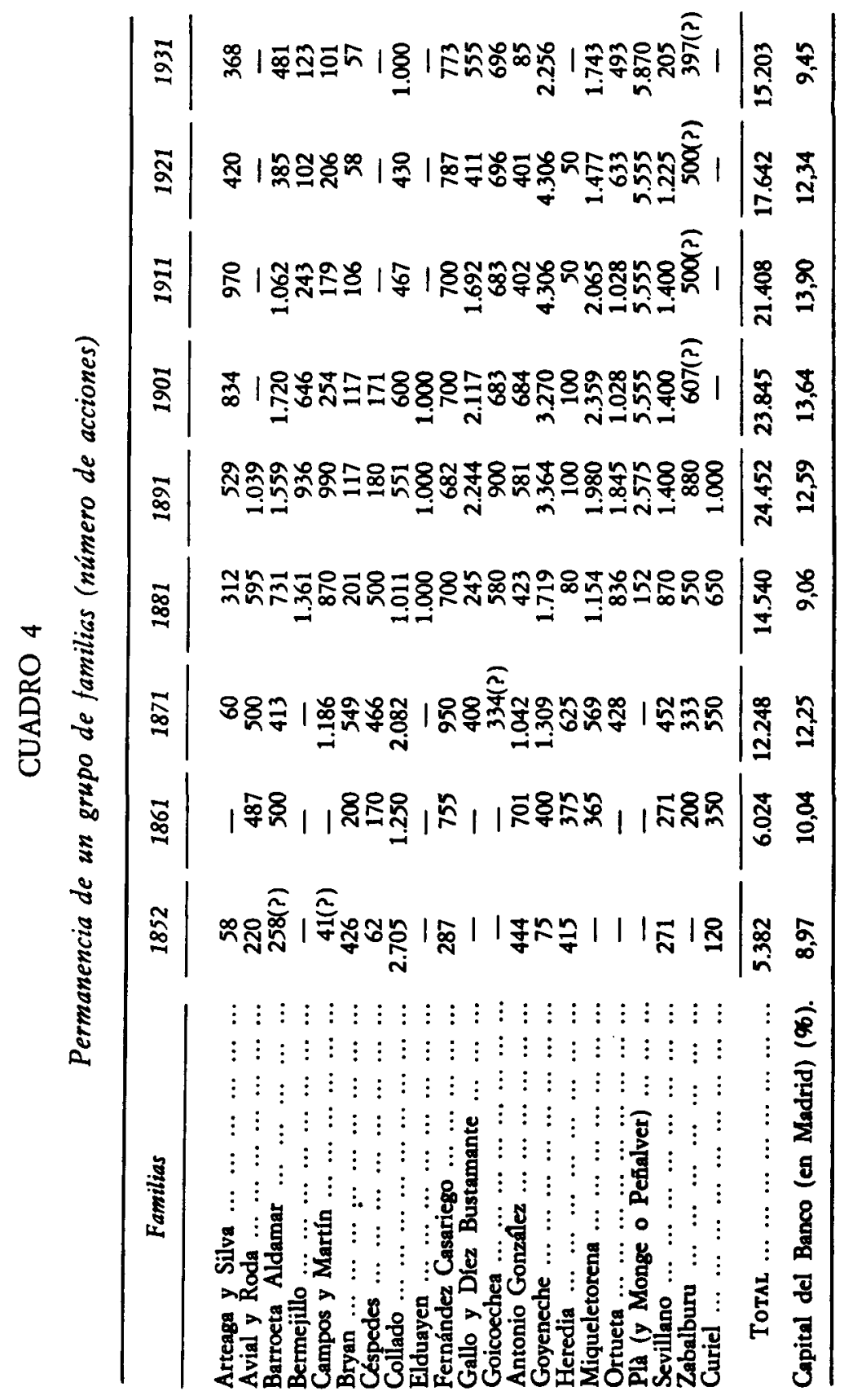


A la vista del Cuadro 4 podemos afirmar que la posición sobresaliente que varios hombres de la política y de los negocios tienen en 1850-60 es recogida por la segunda generación a la altura de 1880 , igual que por los nietos en las primeras décadas del siglo $\mathrm{xx}$. Por lo general, los accionistas han consolidado su situación antes de 1890 , acudiendo a las ampliaciones de capital que tuvieron lugar en $1874-75$ y 1882.83, llegando a controlar del 8 al 14 por 100 de las acciones de Madrid. Otros grandes accionistas que se mantienen durante largo tiempo serían C. Jiménez, Weisweiller, Jacquet, Molinuevo, Roiz de la Parra... y al mismo resultado se llega con el seguimiento de las personas que disponen de título nobiliario. $\mathrm{Da}$ la impresión que las acciones del Banco de España era un activo del que costaba desprenderse con facilidad...

Tal como hemos advertido antes, si no sabemos cuándo empieza la categoría de terrateniente o dónde acaba la de comerciante, sería complicado dar porcentajes de acciones en manos de un grupo social $\mathbf{u}$ otro, mucho más cuando abundan los nombres de mujeres en las listas de accionistas. Igualmente es arriesgado diseñar el "retrato robot" del gran accionista del Banco de España. A lo sumo podemos avanzar algunos rasgos biográficos que son comunes para varios de los principales accionistas de Madrid.

Buena parte de éstos pertenecen a la categoría de comerciantes banqueros de Madrid (Céspedes, F. Casariego, Gaviria, Miqueletorena...), algunos de los cuales eran ya accionistas del Banco de San Carlos en los últimos años ". Han sacado de apuros a los gobiernos liberales con anticipos y suscribiendo empréstitos (Collado, Sevillano, etc.), siendo por ello bien retribuidos, pues en los arreglos de la deuda han tenido preferencia frente a los modestos ahorradores ${ }^{12}$. Se han hecho con buena porción de tierras en el mercado de la desamortización y como prestamistas de una aristocracia en apuros han accedido igualmente a propiedad desvinculada ${ }^{13}$, pero ningún negocio, bien sea colonial o inmobiliario ${ }^{14}$, les está vetado. Constituyen la avanzadilla de la inversión de capital extranjero, especialmente de los Rothschild ${ }^{15}$, y llegarán a ocupar carteras ministeriales o la Presidencia del

"Tedde (1983) y Teresa Tortella (1986).

${ }^{12}$ Exposición (1837): M. Gaviria, J. Guardamino, A. Jordá, N. Carriquiri..., figuran en varias de las operaciones de crédito del 3 de julio de 1836 al 9 de agosto de 1837. Pară uno de estos generosos arreglos, J. Fontana (1977), pp. 236-240. La actuación de estos hombres, «como amigos íntimos y partidarios de Mendizábal», en P. Janke (1974), especialmente pp. 318-327.

${ }^{13}$ La participación de los Collado, F. Lasala, Fernández Casariego, Sevillano, Carriquiri..., en la desamortización aparece documentada en Asturias (Moro), Valladolid (Rueda), Navarra (Donézar), etc. Su función de prestamistas de aristocracia en apuros, en R. Robledo (1984) y Atienza-Mata (1986).

${ }^{14}$ A. Bahamonde (1981), pp. 172 y ss.

is Encontraremos al grupo de siempre en el Consejo de la Sociedad Española Mercantil 
Gobierno, a veces enterrando sueños de progresismo y tornándose acérrimos defensores de la restauración borbónica. Finalmente, bien por vía directa o el matrimonio, los veremos ennoblecidos. Son, en fin, los «modernos» del siglo XIX, los triunfadores de la sociedad liberal...

Si nos referimos a personas jurídicas hay que destacar la importancia que adquieren los Bancos en la lista de 1931; los banqueros privados siempre estuvieron bien representados, como hemos visto antes ${ }^{16}$; ahora, la figura de Banco de Bancos a la que paulatinamente se iba acercando el Banco de España tenía su paralelo en 1931 en lo que respecta al control de parte del capital: ocho Bancos dentro de los 50 primeros accionistas.

Quizá más sobresaliente sea la representación conseguida por diversas instituciones religiosas o fundaciones benéficas. La Fundación Figueroa fue el primer accionista en el siglo xIx y el segundo de 1901 a 1931; el puesto libre dejado por esta Fundación lo ocupó otra, la Fundación benéfica Plà y Peñalver. Si se tięnen en cuenta las acciones del fundador y familiares, este grupo poseerá cerca de 6.000 acciones. Está por estudiar el significado de estas instituciones, cuyas acciones eran inalienables, igual que lo eran las que estaban en manos de diversos mayorazgos, años después de que se hubiera producido la desvinculación. Si se examina la lista de accionistas del Banco de San Carlos se comprueba cómo algunas de estas fundaciones ya estaban allí representadas ${ }^{17}$. El Gobierno había estimulado la compra de acciones, dando preferencia a éstas para inversiones de hospitales, iglesias, dotes religiosas, congregaciones, fundaciones y legados ${ }^{18}$.

En otros casos (cuadro 5) aparecen Cabildos, Seminarios y en general instituciones de ámbito religioso que no parecen tanto herencia del pasado. $¿$ ¿Hasta qué punto estas instituciones no habrán cambiado sus activos, deuda pública recibida en compensación por la desamortización en el Convenio de 1859-60, por acciones del Banco? No lo sabemos. De momento ahí está el hecho de que alguna orden religiosa tuviera más de 1.000 acciones en 1911, que un Colegio de niños huérfanos figurara en los primeros lugares o que en la mayoría de las sucursales los que tienen derecho de asistir a la Junta General sean instituciones benéfico-religiosas (cuadro 5), como si el Banco de España en provincias fuera refugio de Conventos,

e Industrial: G. Tortella (1972), pp. 60, 73. El reciente libro de Otazu (1987) constituye una guía valiosa para seguir en detalle los negocios de varios de estos personajes.

${ }^{10}$ Las listas que aparecen en Tedde (1974), p. 305, y, sobre todo, J. R. García López (1985) lo confirman.

${ }^{17}$ En el Apéndice (p. 579) figuran, entre otras instituciones, la Fundación Figueroa o el Real Hospital de Santiago. Algunos particulares han debido destinar estas acciones para financiar luego Obras Pías y Fundaciones: la Marquesa de Cerralbo, con la Obra Pía Motezuma; Sancho Larrea, con la Fundación de este nombre.

14 E. J. Hamilton (1970), p. 209. Para más detalle, T. Tortella (1986). 


\section{CUADRO 5}

Instituciones con más de 50 acciones en Sucursales del Banco de España Año 1911

Barcelona
Bilbao
Burgos
Cádiz
Ciudad Real
Coruña
Cuenca
Gijón
León

Lérida

Logroño

Malaga

Orense

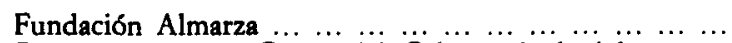

Patronato Puig y Cuñer del Colegio de huérfanos pobres de San Julián de Vilatorta $\ldots \ldots \ldots \ldots \ldots$

Fundación del Colegio de Ntra. Señora del Carmen (Portugalete) $\ldots \ldots \ldots \ldots \ldots \ldots \ldots$

Acciones

Casa de las Hermanitas de los pobres ancianos desam-

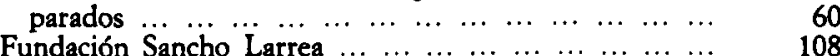

Hospital de Mujeres Ntra. Señora del Carmen ... ... 136

Fábrica de la iglesia parroquial de San Pedro ... ... ... 235

Fábrica del Santuario del Santísimo Cristo (Membrilla). $\quad 62$

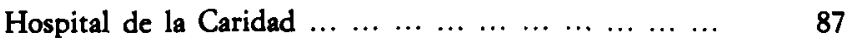

Escuelas Martínez de la Mata (Patronos Sres. Canó-

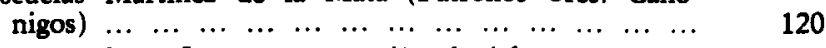

Asilo de Santa Laureana para niñas huérfanas ... ... ... 102

Gobernador eclesiástico del Obispado de Astorga ... ... 56

Hospital de San Antonio Abad $\ldots . \ldots \ldots \ldots$

Escuelas Valcárcel (Patronos los párrocos de Villabuena

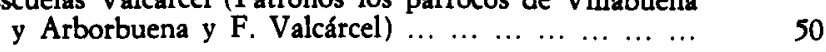

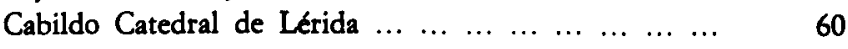

Rvda. Madre Superiora General de Religiosas Adora-

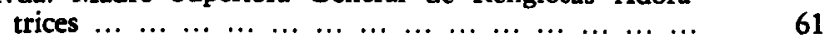

Colegio de San Telmo $\ldots \ldots \ldots \ldots \ldots$

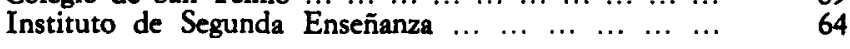

Patronos de la Memoria de Escuela y Capellanía Prado

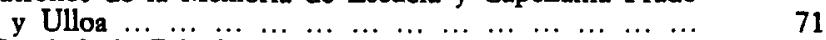

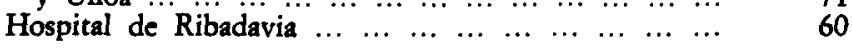

Oviedo Colegio de Ntra. Señora del Carmen. Cabos de Pravia. 56

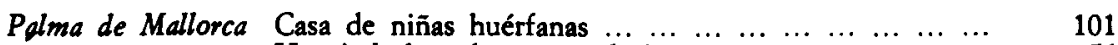

Hospital de pobres convalecientes $\begin{array}{llllllll}\ldots & \ldots & \ldots & \ldots & \ldots & \ldots & & 101 \\ \text { Ho }\end{array}$

Pamplona $\quad$ Patronos de Escuelas Espoz y Vergara ... $\ldots \ldots \ldots \ldots \ldots$

\begin{tabular}{lllllllllllll} 
Salamanca & Obra Pía Motezuma & $\ldots$ & $\ldots$ & $\ldots$ & $\ldots$ & $\ldots$ & $\ldots$ & $\ldots$ & $\ldots$ & $\ldots$ & $\ldots$ & \\
\hline
\end{tabular}

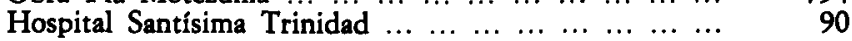

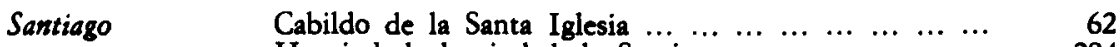

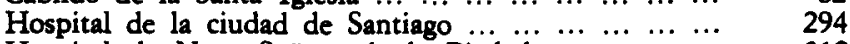

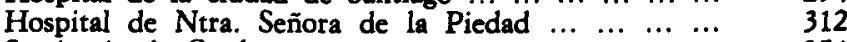

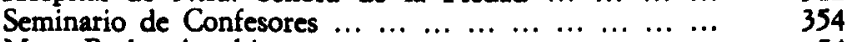

$\begin{array}{llllllllll}\text { Muy. Rvdo. Arzobispo } & \ldots & \ldots & \ldots & \ldots & \ldots & \ldots & \ldots & \ldots & \ldots \\ \end{array}$

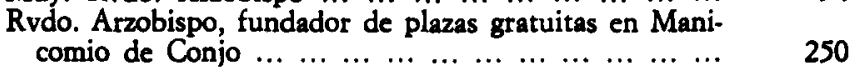

$\begin{array}{llllllllllll}\text { Sevilla } & \text { Hospital de la Caridad } \ldots & \ldots & \ldots & \ldots & \ldots & \ldots & \ldots & \ldots & \ldots & & 67\end{array}$ 
CUADRO 5 (continuación)

Instituciones que son accionistas en Sucursales del Banco de España. Año 1911

\begin{tabular}{|c|c|c|}
\hline & & Acciones \\
\hline Teruel & $\begin{array}{l}\text { Rvdo. cura párroco y Ayuntamiento de La Hoz. Fun- } \\
\text { daciones Cabañero } \ldots \ldots \ldots \ldots \\
\end{array}$ & 97 \\
\hline Toledo & $\begin{array}{l}\text { Colegio de doncellas de Ntra. Señora de los Remedios. } \\
\text { Hospital de Santiago de los Caballeros } \ldots \\
\text { Instituto de Segunda Enseñanza } \\
\text { Insto }\end{array}$ & $\begin{array}{r}228 \\
180 \\
70\end{array}$ \\
\hline Vitoria & 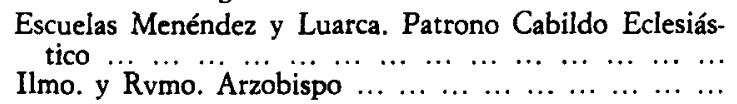 & $\begin{array}{r}100 \\
55\end{array}$ \\
\hline Zaragoza & 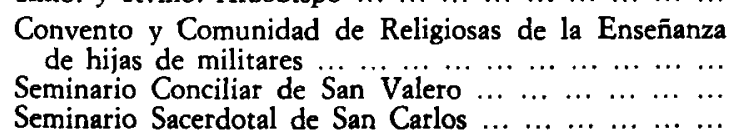 & $\begin{array}{r}60 \\
145 \\
107\end{array}$ \\
\hline
\end{tabular}

Patronatos y Cabildos. Serían algunos de los «seráficos accionistas» a los que se refiere $L$. Rodríguez en su librito...

De acuerdo con un Informe del Banco de España, de los 15.376 accionistas del Banco en 1931, 807 eran fundaciones de carácter benéfico o docente y poseían 42.287 acciones, lo que supondría un 12 por 100 . En este dato se apoyaba el Consejo del Banco para defenderse de nuevos impuestos que supondrían, según él, una desvalorización de las acciones, recayendo el perjuicio «principalmente sobre instituciones benéficas y sobre el ahorro modesto" ${ }^{19}$. Por más que el poder de concentración de los grandes accionistas no hubiera disminuido, la imagen de un accionariado modesto y, además, sin ánimo de lucro constituía un buen argumento para luchar por el mantenimiento de los beneficios, un asunto siempre candente, como veremos.

\section{Una nota sobre los beneficios del Banco de España}

Hacia 1900, el Banco de España aparecía a la consideración de los analistas extranjeros o españoles como una institución con rasgos atípicos en la comparación con otros Bancos similares. En primer lugar, se merecía todas las críticas por su despreocupación e indiferencia en la cuestión de los cam-

\footnotetext{
"Proyecto (1931), p. 9.
} 


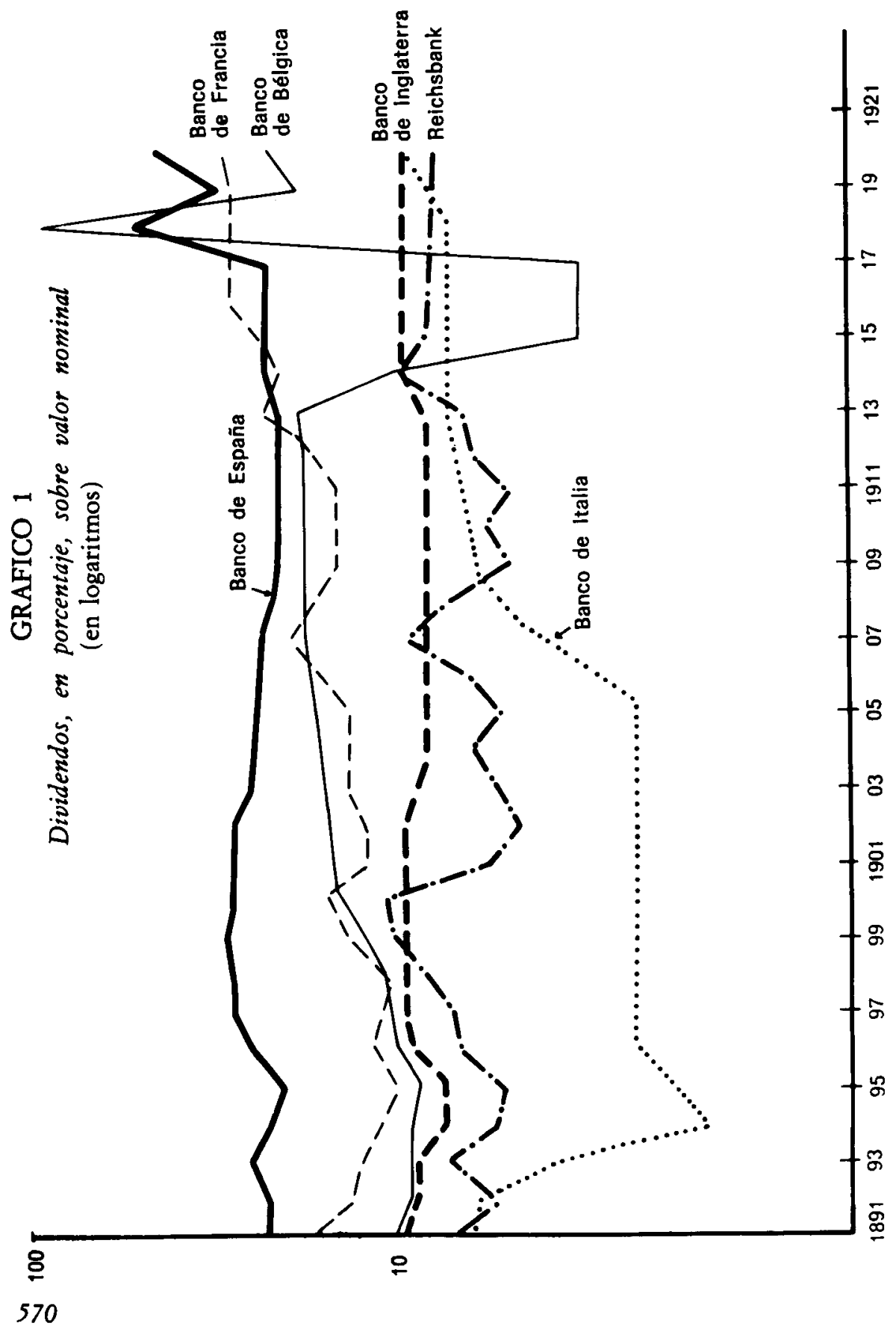


bios ${ }^{20}$. Además, su dependencia con el Tesoro era excesiva: «Investíguese como se quiera por Europa; no se encontrará un Banco (...) a quien el Tesoro deba más de mil millones de francos» ${ }^{21}$. A diferencia del resto de países —añadían otros- donde el tipo de interés de la deuda pública se mantenía por debajo del que regía para el descuento o los préstamos, aquí ocurría al contrario ${ }^{22}$. Por último, el Banco de España, comportándose exclusivamente como una institución privada, lograba repartir dividendos que rara vez alcanzaban otras instituciones europeas similares ${ }^{23}$.

Era este último aspecto de los beneficios al que más sensibles se mostraban los contemporáneos, pues en cierto modo a como hoy ocurre con los beneficios que consiguen las instituciones financieras en momentos de crisis económica, también ellos eran testigos de que «los años de calamidades y de duras pruebas para el país fueron precisamente los de mayores beneficios para el Banco» 24 .

No había nada anómalo en esta situación. Mientras los negocios del Banco estuvieran en socorrer al Tesoro (y hasta 1900 el compromiso fue contundente), a mayores apuros de éste le debía corresponder el máximo de beneficios de la institución bancaria ${ }^{25}$. Así ocurrió con motivo de las guerras coloniales: en 1899 se reparten 50 millones de pesetas en beneficios y en 1900 se consigue, por el momento, la máxima cotización en las acciones. No hace falta, pues, multiplicar citas sobre este fenómeno acudiendo a autores muy críticos, alguno de los cuales, paradójicamente, eran accionistas del Banco ${ }^{26}$. Son las mismas Memorias de la institución las que no ocultan, en otra coyuntura político-económica comprometida, cómo a pesar del «estado crítico del país, tan fatal para las transacciones mercantiles», el Banco siguió,

${ }^{20}$ E. Théry, «L'Economiste Européen», en La Reforma (1902), p. 115.

21 P. Leroy-Beaulieu, en La Reforma (1902), p. 171. Idéntica crítica, veinte años después, en F. Bernis (1921), p. 14.

${ }^{22} \mathrm{La}$ comparación con varios países durante 1890-1902, en L. V. Paret (1921), pp. 173. 174. Romanones calificó el fenómeno de «pecado verdaderamente imperdonable»: DSSC, 10 noviembre 1904 , p. 968 . Con esto sólo se favorecía la especulación y la holganza: Cámara de Comercio de Sabadell (1890).

${ }^{31}$ El gráfico 1 se basa en Paret (1921), p. 175. Si el Banco de Bélgica superó al Banco de España en 1918 fue porque ese año se distribuyó un considerable remanente no repartido en los años de ocupación alemana.

${ }^{24}$ F. Bernis (1921), p. 27, lo ilustra con una cronología de 1863 a 1920. Extrañamente, no se ha consultado demasiado este librito. Por encima del respeto que le inspiraban el Consejo del Banco o Cambó («inteligente y bien intencionado Ministro»), Bernis anteponía la consideración de «los capitales privados como un producto penoso de la historia y del trabajo de todos, como el fruto exquisito de muchos padres" (p. 6).

${ }^{25} \mathrm{La}$ «larguezaw en repartir dividendos esos años, mientras los tenedores de la deuda pública veían recortados sus haberes, es criticada en J. Sánchez de Toca (¿1915?), pp. 15-17.

${ }^{26}$ Romanones figura en la lista de 1921 con 51 acciones. Más destacado es J. Sánchez de Toca, cuyo grupo familiar disponía como mínimo de 665 acciones en 1891 . 
no obstante, «su acostumbrada marcha, sin perturbación en sus operaciones, ni menoscabo en sus intereses» ${ }^{27}$.

Pronto se levantaron voces para exigir que el Tesoro tuviera participación en los beneficios del Banco. Así lo hizo tempranamente la Cámara de Comercio de Barcelona en 1891, oponiéndose a la concesión del privilegio de emisión por largos períodos y sin contrapartida ${ }^{28}$, justificando su fama posterior de ser Barcelona «enemiga declarada del Banco de España» ${ }^{29}$. Moret recordaba en 1904 que en todos los países el Estado tenía parte en las utilidades del Banco central ${ }^{30}$, y Navarro Reverter en el proyecto de 1906 o Santiago Alba más tarde intentaron frustradamente la intervención directa del Estado en los beneficios.

Por su parte, los defensores de la institución argüían que ya participaba demasiado el Estado indirectamente, vía fiscal, al gravar las utilidades o no pagar réditos por el anticipo de 150 millones de pesetas concedidos en 1891 o los pagarés de Ultramar. No fue hasta la Ley de Ordenación Bancaria de 1921 cuando el Estado fijó su participación en la distribución de los beneficios en una escala progresiva que se iniciaba cuando los dividendos excedieran el 10 por 100 del valor nominal de las acciones, todo ello «como compensación extraordinaria a la prórroga del privilegio de emisión». Los representantes del Banco de España se habian opuesto frontalmente al proyecto y expusieron un argumento que merece la pena ser transcrito:

Que en lo posible, y puesto que hace más de treinta y cinco años la estimación de las acciones no se aleja del quíntuplo de su valor nominal, precio al que han sido adquiridas a través de muchas transmisiones por la casi totalidad de los actuales accionistas, devengando los impuestos de todo género en razón a aquel valor efectivo, que representa una suma de riqueza de 750 millones de pesetas al módico interés de 4 por 100 , sería de justicia, equidad y pública conveniencia no imponer gravámenes desconsiderados al Banco que implicasen inusitada depreciación de las acciones ${ }^{31}$.

\footnotetext{
${ }^{27}$ Memoria (1871 y 1873).

${ }^{28}$ Se defendió entonces que el Tesoro participara en los beneficios al 50 por 100: Cámara de Comercio (1920), p. 8.

${ }^{20} \mathrm{La}$ expresión es de P. Corominas, después de recoger las opiniones de G. Graells, M. Girona, F. Rahola y otros que miraban con simpatía el proyecto de Urzáiz de 1902, no por su viabilidad, sino por su tendencia a poner límites a «los excesos del monopoliow: La Reforma (1902), p. 170.

3o DSSC, 14 noviembre 1904 , p. 1033.

${ }^{31}$ Voto particular de los vocales del Banco de España en la Junta creada por el Ministerio de Hacienda, en Anuario (1919), p. 250.
} 
Hasta aquí el voto particular de los consejeros. El argumento de que la casi totalidad de loś accionistas lo fueran entonces por la adquisición de las acciones al 500 por 100 se desmiente en gran medida por lo expuesto antes: buena parte de las acciones en poder de los titulares a principios de siglo habian sido adquiridas por sus antecesores no a 2.500 , sino a 500-550 pesetas y en consecuencia el interés no era tan «módico», debiéndose acercar más de una vez al 20 por 100 , promedio de los dividendos respecto al nominal de las acciones durante 1876-1918. Habría que tener en cuenta en cualquier caso el beneficio resultante por la plusvalía en caso de desprenderse de parte de los títulos.

Respecto al derrumbe en la cotización de las acciones, que los consejeros preveían a causa de la asociación de Banco y Tesoro en la explotación de un negocio, según ellos, «modesto», hay que decir que estos temores no se cumplieron, sino al contrario: el cenit en la cotización se conseguía precisamente en 1926 con un tipo de 680 por $100^{32}$.

Como muestra el gráfico 2, una vez que se consiguió el monopolio de emisión (hasta entonces las acciones se movían en los márgenes de 100-200 enteros), la escalada en la cotización fue, con las inevitables fluctuaciones, en progresivo aumento. El Banco seguía su «acostumbrada marcha», no afectándole, por ejemplo, el que desde principios de siglo se desprendiera de gran parte de la cartera de renta ${ }^{33}$; en esos años de 1900-1918 las acciones superaron el promedio del 450 por 100 y no porque aumentara en exceso su dedicación mercantil ${ }^{34}$. Otros negocios que no coincidían exactamente con la intención de desarrollar la industria o el comercio llenaban el hueco dejado por el endeudamiento del Tesoro; por ejemplo, en 1917 se obtuvieron 30 millones de pesetas de beneficios extraordinarios por la adquisición de oro ${ }^{35}$, pero no aceptó antes ni después ninguna responsabilidad en materia de cambios como debiera corresponder a un Banco de Bancos. Se negó sistemáticamente a desprenderse de las reservas de oro basándose en consideraciones que no resisten la crítica económica, como ha expuesto P. Martín

32 Las fuentes para la elaboración del gráfico 2 son: E. Martínez (1922), para los años 1856-60 y $1872-74$ (promedio de la cotización máxima y media anual); mientras que los años 1861-71 y 1875-1914 son promedio de las cotizaciones semanales en G. Torte-
lla (1972) y R. Anes (1974), respectivamente. El periodo 1915-36, en Anuario (1944-45).

${ }_{33}$ R. Anes (1974), p. 213.

34 Tuvieron mayor crecimiento los préstamos y créditos con garantía personal que los descuentos comerciales, que si crecieron espectacularmente en 1918 fue por el préstamo de más de 400 millones de pesetas al Banco de Francia: Paret (1921), p. 171. La serie para 1901-35, en Martín Aceña (1985), p. 36.

${ }_{33}$ Esta cantidad, distribuida en forma de bonos, se convertiría luego en acciones en la ampliación de capital de 1921: Anuario (1919), p. 246. Esta fue una de las victorias del Consejo del Banco frente al dictamen de la Junta que preparó el proyecto de ley de ordenación bancaria. 


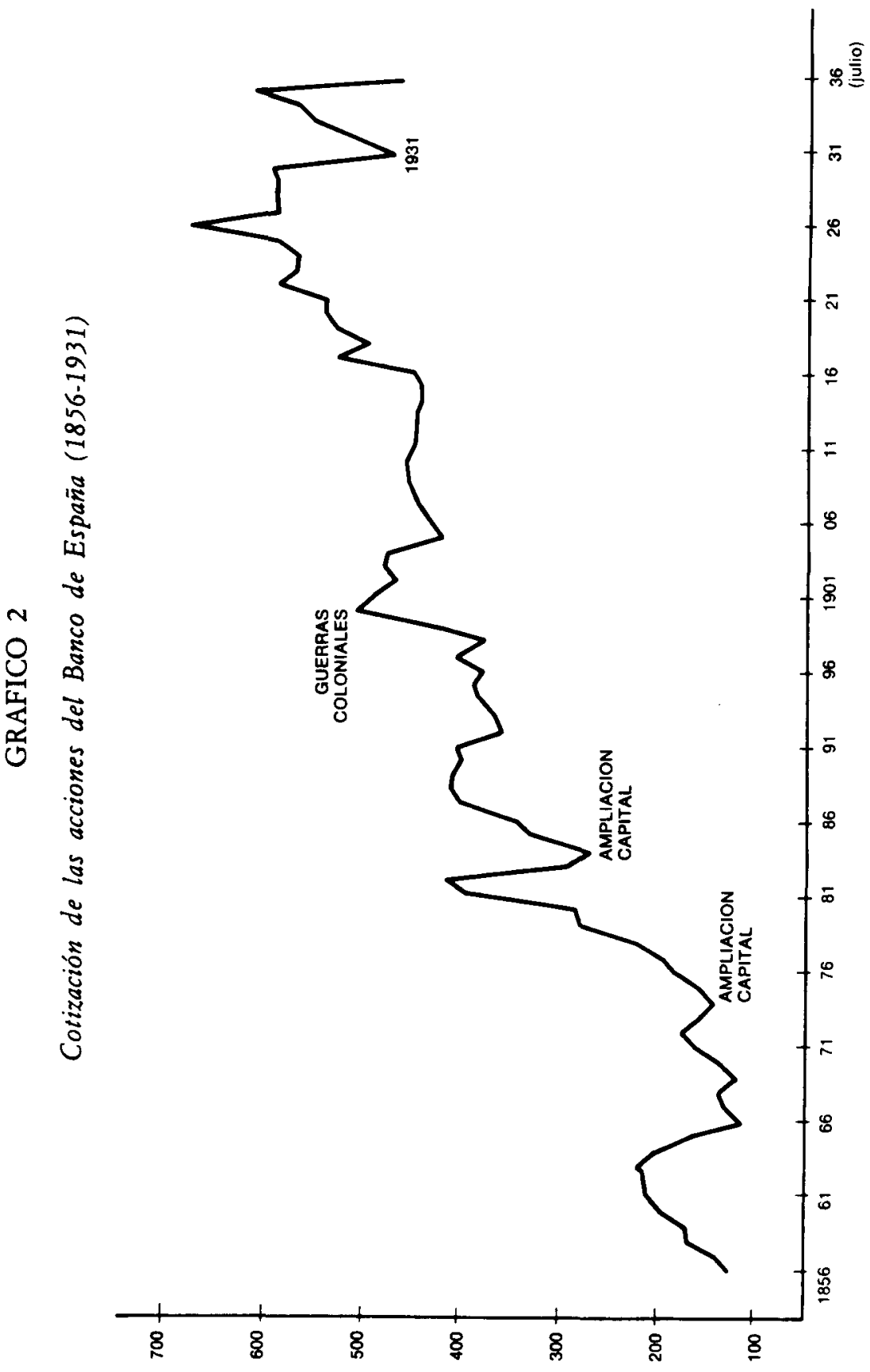


Aceña, pero que afectaban a los intereses de los accionistas, que consideraban el oro patrimonio exclusivo suyo ${ }^{36}$.

Es comprensible la sensibilidad que mostraba el Consejo del Banco en 1919 o en 1931 por el tema de los beneficios, pues su obligación, como la de cualquier otra sociedad por acciones, era intentar su maximización, lográndolo a través de su vinculación con el sector público, que fue mucho más intensa hasta principios del siglo Xx. De 1875 a 1900, el total de beneficios liquidos, una vez descontadas todas las contribuciones e impuestos, ascendió a 726,8 millones de pesetas, es decir, más de cinco veces el capital medio del Banco... ${ }^{37}$ Cualquiera de las estimaciones sobre los beneficios que quedaron en manos españolas por la exportación de vinos o minerales en aquellas fechas empalidecen ante aquella cifra.

De acuerdo con estos resultados, yo no estaría tan seguro de que la colaboración del Banco de España con la Hacienda fuera una opción «impuesta», unilateralmente desde las instancias políticas, con el fin de solventar los apuros crónicos de aquella institución ${ }^{38}$; en todo caso se trató de una opción muy ventajosa. ¿Cómo discriminar, por otra parte, en el maridaje del Banco con la Hacienda lo que era presión del sector público de lo que era búsqueda del interés particular por parte de los representantes de los accionistas? Idéntica confusión hallaremos en otros planteamientos de la política económica, pues será el mismo grupo de la burguesía, al que mayoritariamente pertenecían los grandes accionistas, quien más se beneficiará ante el socorrido recurso de aumentar la circulación fiduciaria o las emisiones de deuda pública para salvar el desfase provocado por la «petrificación del sistema impositivo».

Se puede discutir si la actuación de los sucesivos gobiernos, como principales destinatarios de los recursos del Banco, fue adecuada o no para el crecimiento económico. En tal sentido $G$. Tortella ha sugerido que el rendimiento económico habría sido probablemente mayor si los fondos del Banco se hubieran canalizado más hacia la actividad privada ${ }^{39}$; pero la opción de Banco de desarrollo en vez de la de prestamista público no siempre fue obstaculizada por el Gobierno, sino al contrario. Voces autorizadas se levantaron contra la Ley Rodrigáñez que fijaba la enajenación de títulos de deuda y acciones de la Compañía Arrendataria de Tabacos para pasar a una cartera

${ }^{36}$ Martín Aceña (1984), pp. 41, 303. Bernis criticó duramente las adquisiciones de oro como una inmovilización a costa de la circulación de la riqueza e inútil para dotar de valor a la circulación de billetes (1921).

${ }_{37}$ Memoria(s) (1875-1900). He deducido todos los impuestos del Tesoro, que sumaron aproximadamente 162 millones de pesetas. La serie de los beneficios (antes de impuestos) de 1874 a 1915 , en R. Anes (1974), p. 161.

38 G. Tortella $(1970 b)$, p. 311 .

39 Ibidem. 
mercantil, pues «se prescindía de los intereses de los accionistas» y se los exponía a la "apatía e ignorancia de muchos españoles que consideran deshonroso suscribir un documento de crédito" ${ }^{40}$. Efectivamente era mucho más seguro apoyarse en la ottopedia del sector público: sólo entre 1895 . 1905 los intereses pagados por el Tesoro al Banco en razón de préstamos ascendieron a 196 millones de pesetas ${ }^{41}$, casi un tercio más que los recursos propios del Banco. Todavía en 1919, por mucho que se jaleara la necesidad de evitar una vinculación excesiva del Tesoro con el Banco, se procuraba al mismo tiempo no eliminar la Deuda Pública de su cartera, «al objeto de conseguir el equilibrio de sus beneficios, que de otra suerte quedarían más expuestos a las fluctuaciones de la cartera mercantil» ${ }^{42}$.

\section{Recapitulación y conclusiones}

El número de accionistas del Banco de España se multiplicó por siete de 1871 a 1931, gracias sobre todo a la representación que fueron teniendo en las sucursales, pero sin que ello mermara el poder que tenían los grandes accionistas de Madrid: si nos referimos a los 50 primeros, cuyos nombres aparecen en el apéndice, controlaron de un quinto a un tercio de las acciones de la Central que hasta 1911 dispuso de la mayoría del capital de la institución. Conviene destacar la escasa representación que tenía Cataluña, muy por debajo, como era de esperar, de la que ostentaba Madrid, pero inferior también a la de otras regiones nada industrializadas.

Aunque es difícil asignar una profesión o actividad económica para clasificar al gran accionista (mucho más si se tiene en cuenta el número de mujeres que hay entre ellos), suele abundar el hombre de negocios, el banquero privado que a la vez es terrateniente salido de las filas de la desamortización, y por tanto los compromisos económicos son muy variados. Pueden coincidir con los que D. Mateo del Peral estableció para las autoridades económicas, es decir, fuerte vinculación con los negocios ferroviarios, sociedades de crédito y con representación en diversas industrias. En todo caso, lo que sí sabemos es que el gran accionista no se corresponde bien con la figura pasiva de un rentista (que a mayor abundamiento pertenece a una institución privilegiada que reparte siempre buenos dividendos).

Bien es cierto que en los primeros lugares figuran también fundaciones y otras entidades de carácter religioso o benéfico, una presencia que puede

* J. M." Jiménez (1905), pp. 208-209. La sustitución de la cartera de renta por una cartera mercantil no contó con el apoyo entusiasta del Banco. Véase R. Anes (1974), p. 200.

"1 J. M." Tallada (1946), p. 130.

42 Voto particular de los consejeros: Anuario (1919). 
resultar desconcertante. En algunos casos es el resultado de haber canjeado las antiguas acciones del Banco de San Carlos, pero no puede decirse lo mismo de otras instituciones. Aparentemente menos preocupadas por los asuntos terrenales, parece, sin embargo, que a la hora de decidir dónde invertir, acertaron al escoger una empresa sólida y que diera buenos dividendos, tanto en la paz como en la guerra (sobre todo en ésta), con monarquía o república.

Alguien podría pensar que con otros accionistas más «dinámicos» que el conjunto variopinto que lo formaba, la política del Banco hubiera sido más beneficiosa para el crecimiento económico del país, pero parece que mientras persistiera el déficit crónico de la Hacienda era muy tentador para una empresa privada que explotaba un negocio público (que se basó en gran medida en la financiación del déficit) seguir aprovechándose de esta oportunidad. Cuesta imaginarse que adoptaran voluntariamente otras posturas más acordes con un Banco central si ello iba en perjuicio de los beneficios y para demostrarlo están sus maniobras para mantener acciones de la Compañía de Tabacos, tan poco ortodoxas para un Banco de depósitos y menos aún para un Banco central de emisión, en expresión de Tortella ${ }^{43}$, o, en general, la oposición frente a la Ley Rodrigáñez o el proyecto de Ley de Ordenación Bancaria hasta lograr que se hiciera en los términos más favorables para el Banco.

¿No podría el Estado haber mantenido otra actitud respecto al Banco? Si durante largo tiempo permitió que el Banco incumpliera algunos apartados de la Ley de 1902 o a través de una legislación ambigua se mostraba incapaz de exigirle que desempeñara funciones en política monetaria debió ser por la situación apurada en que se hallaba sistemáticamente el Tesoro, con la consiguiente dependencia del instituto emisor y el deseo de no perjudicar a los accionistas (por supuesto donde mejor se percibe esta intención es al constatar que durante casi medio siglo el Tesoro no pudo participar directamente en los beneficios de un Banco que tenía el monopolio de emisión). También habría que añadir, como indican las listas de accionistas, en las grandes coincidencias que había entre éstos y los responsables ministeriales, de modo que parece excesivamente sutil intentar deslindar respon. sabilidades entre Ministerio de Hacienda y Banco cuando el pasillo entre uno y otro era tan corto y tan frecuentado por las mismas personas. Por esto mismo me parece que habría que prescindir un poco de la imagen que a veces se ha dado de un Banco que de modo pasivo dejaba que una Hacienda tan necesitada como voraz se apropiara de «sus" recursos.

Es posible que mis argumentos aparezcan sesgados por la insistencia en

${ }^{43}$ G. Tortella (1970 b), p. 298. 
lo bien que les iba a los accionistas del Banco o por el mayor protagonismo que habría que concederles. Pero me parecía oportuno, una vez identificados a sus principales titulares, mostrar otra impresión distinta de la que resulta de las Memorias del Banco (o de libros de la época inspirados acríticamente en ellas), que para justificar los beneficios hablaban de la «sabiduría de la administración» (la piedra filosofal de la institución), mientras que los préstamos al Tesoro aparecían como «servicios patrióticos en momentos cruciales»... Tal es el caso de los libros de Galvarriato, que además se encargaba de insistir, para defenderse de la participación directa de beneficios en que el Banco de España era «una finca buena y de saneados rendimientos para el Estado» ${ }^{44}$.

Más ecuánime parece Ramón de Santillán en la parte del Banco que le correspondió historiar, pues al mismo tiempo que exponía el enderezamiento efectuado en la administración del Banco, mostraba sin reparos cómo crecían las utilidades de los dividendos «de modo asombroso" y ello gracias a los fondos públicos que había en cartera. Algo así ocurrió en 1859, año en que le tocó aguantar la «oposición organizada» de todos los accionistas, deseosos de percibir dividendos por encima del 12 por 100 , aunque fuera a costa de evaluar de modo irregular los balances. Santillán apostilló no sin amargura: «La Junta General de 1859, en que uno sólo de los concurrentes tomó la palabra en favor de la administración vino a demostrar una vez más la tendencia de estas sociedades a comprometer hasta su misma existencia por la obtención de gruesos dividendos» ${ }^{45}$.

* Galvarriato (1921), p. 74. Dos años después calificaba la Ley Cambó como «el ejemplar más absurdo de la exuberante fauna legislativa españolan: (1923), p. 80.

4 R. de Santillán (1865), tomo II, p. 161. 
APENDICE

Los 50 grandes accionistas del Banco de San Carlos (1785), Nuevo Banco de San Fernando (1852) y Banco de España (1861-1931)

ANO 1785

\begin{tabular}{|c|c|c|}
\hline$N .{ }^{\circ}$ & TITULARES & Acciones \\
\hline $\begin{array}{l}1 \\
2 \\
3 \\
4 \\
5 \\
6 \\
7 \\
8 \\
9 \\
10 \\
11 \\
12 \\
13 \\
14 \\
15 \\
16 \\
17 \\
18 \\
19 \\
20 \\
21 \\
22 \\
23 \\
24 \\
25 \\
26 \\
27 \\
28 \\
29 \\
30 \\
31 \\
32 \\
33 \\
34 \\
35 \\
36 \\
37 \\
38 \\
39 \\
40 \\
41 \\
42 \\
43 \\
44 \\
45 \\
46 \\
47 \\
48 \\
49\end{array}$ & 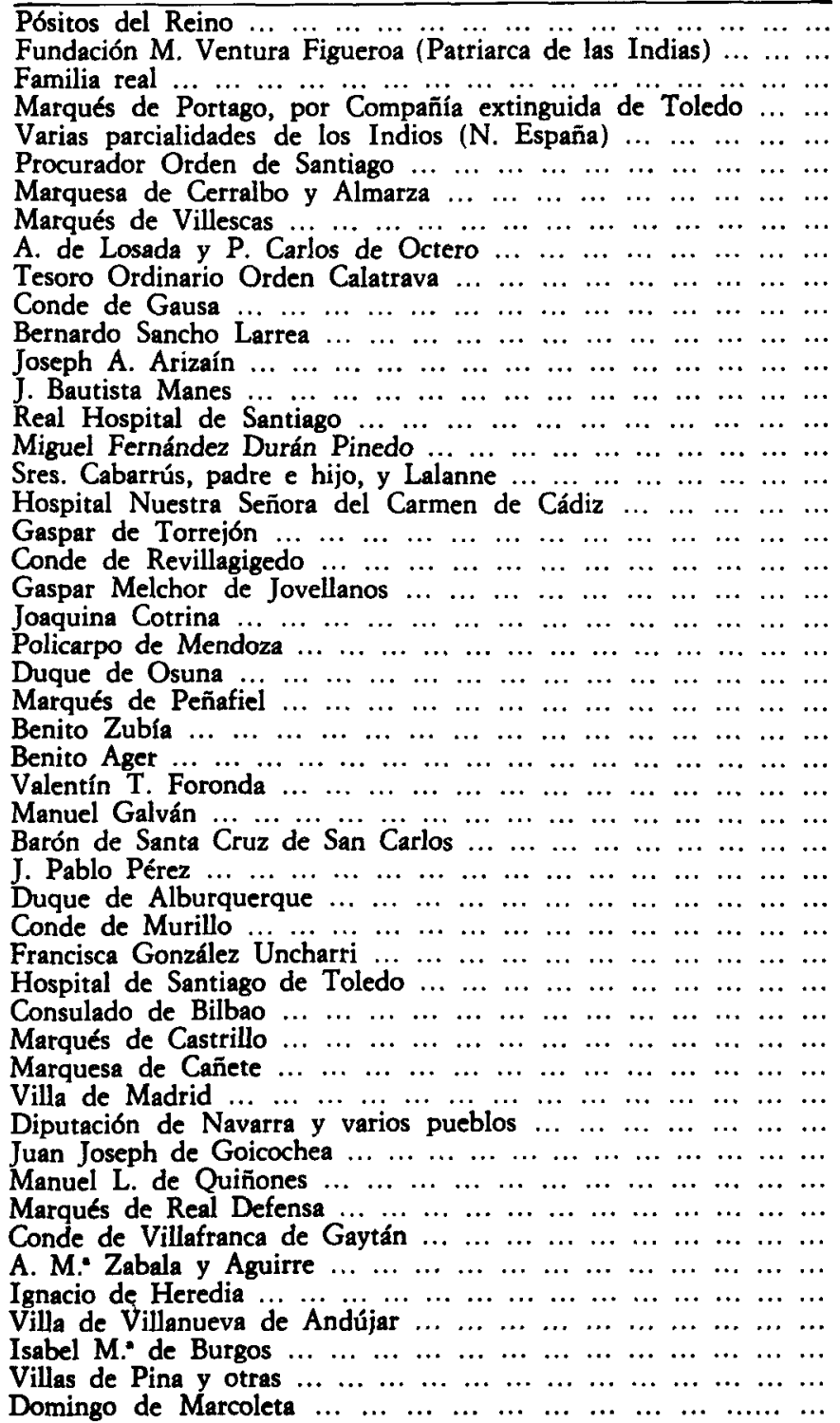 & $\begin{array}{l}8.650 \\
2.500 \\
1.500 \\
1.381 \\
1.343 \\
950 \\
800 \\
760 \\
600 \\
575 \\
507 \\
507 \\
500 \\
400 \\
347 \\
330 \\
318 \\
290 \\
275 \\
250 \\
250 \\
250 \\
225 \\
232 \\
217 \\
175 \\
169 \\
165 \\
150 \\
150 \\
150 \\
147 \\
144 \\
141 \\
140 \\
140 \\
139 \\
135 \\
134 \\
127 \\
125 \\
125 \\
124 \\
125 \\
120 \\
119 \\
110 \\
110 \\
106 \\
103 \\
\end{array}$ \\
\hline & & 27.330 \\
\hline
\end{tabular}

Fueste: Quarta Junta (1786). Se agregan alqunas inscripciones que pertenecian a la misma familia. 
ANO 1852

\begin{tabular}{|c|c|c|}
\hline $\boldsymbol{N} .0^{\circ}$ & $T J T U L A R E S$ * & Acciones \\
\hline $\begin{array}{l}1 \\
2 \\
3 \\
4 \\
5 \\
6 \\
7 \\
8 \\
9 \\
10 \\
11 \\
12 \\
13 \\
14 \\
15 \\
16 \\
17 \\
18 \\
19 \\
20 \\
21 \\
22 \\
23 \\
24 \\
25 \\
26 \\
27 \\
28 \\
29 \\
30 \\
31 \\
32 \\
33 \\
34 \\
35 \\
36 \\
37 \\
38 \\
39 \\
40 \\
41 \\
42 \\
43 \\
44 \\
45 \\
46 \\
47 \\
48 \\
49 \\
50\end{array}$ & 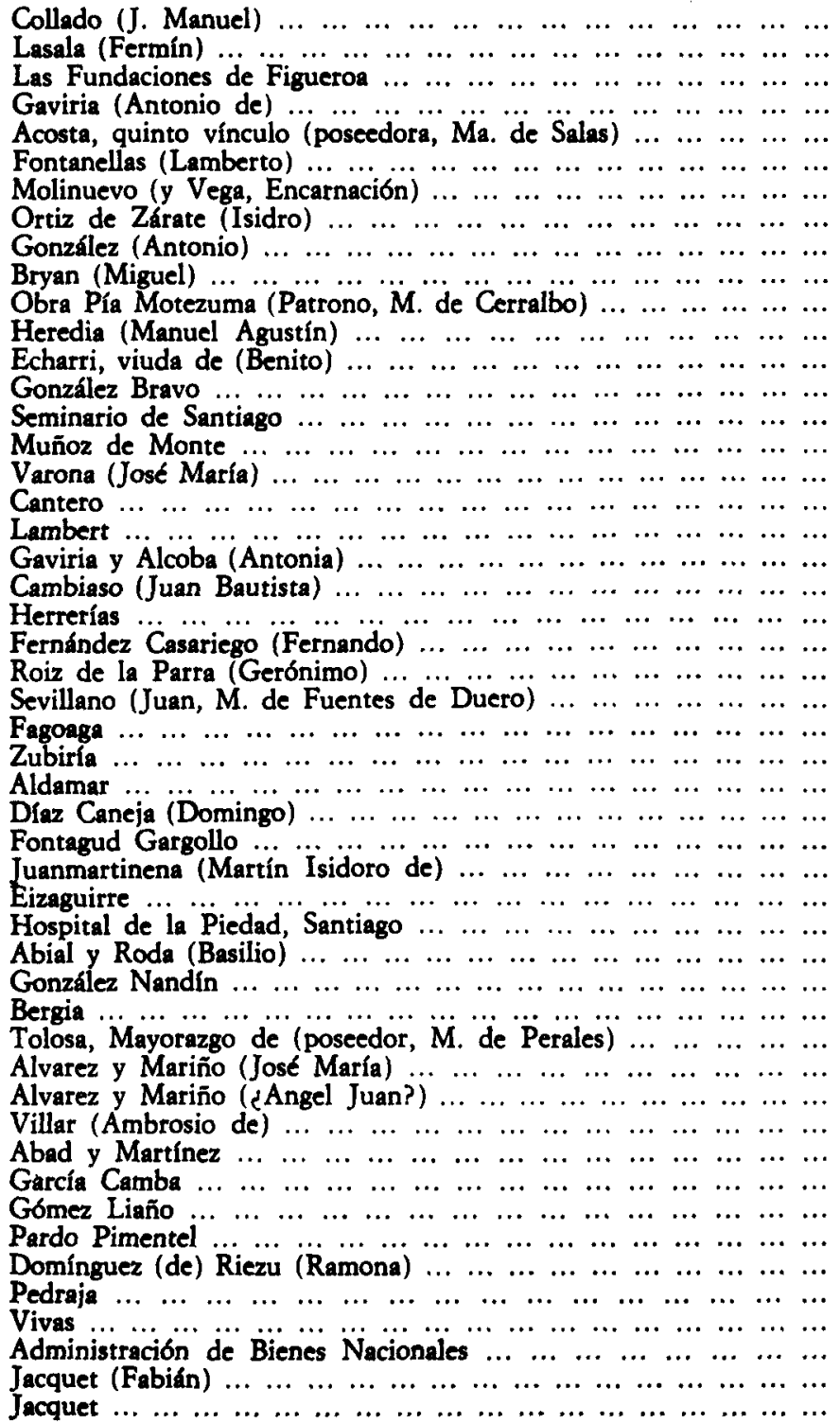 & $\begin{array}{r}2.705 \\
1.394 \\
1.250 \\
633 \\
607 \\
600 \\
504 \\
456 \\
444 \\
426 \\
400 \\
375 \\
365 \\
350 \\
339 \\
338 \\
335 \\
333 \\
317 \\
304 \\
300 \\
291 \\
287 \\
277 \\
271 \\
270 \\
260 \\
258 \\
250 \\
250 \\
250 \\
240 \\
227 \\
220 \\
210 \\
202 \\
194 \\
188 \\
188 \\
185 \\
178 \\
175 \\
175 \\
170 \\
157 \\
155 \\
154 \\
152 \\
150 \\
150\end{array}$ \\
\hline & & 18.909 \\
\hline
\end{tabular}

* Figura entre paréntesis el nombre propio del accionista, deducido a partir de listas postertores. Fumerre: Archivo del Banco de Bepaña, Sección Secretaría, lerajo 463. 


\begin{tabular}{|c|c|c|}
\hline \multicolumn{3}{|c|}{$\mathrm{ANO} 1861$} \\
\hline $\mathrm{N} .{ }^{\circ}$ & TITULARES * & Acciones \\
\hline $\begin{array}{l}1 \\
2 \\
3 \\
4 \\
5 \\
6 \\
7 \\
8 \\
9 \\
10 \\
11 \\
12 \\
13 \\
14 \\
15 \\
16 \\
17 \\
18 \\
19 \\
20 \\
21 \\
22 \\
23 \\
24 \\
25 \\
26 \\
27 \\
28 \\
29 \\
30 \\
31 \\
32 \\
33 \\
34 \\
35 \\
36 \\
37 \\
38 \\
39 \\
40 \\
41 \\
42 \\
43 \\
44 \\
45 \\
46 \\
47 \\
48 \\
49 \\
50\end{array}$ & 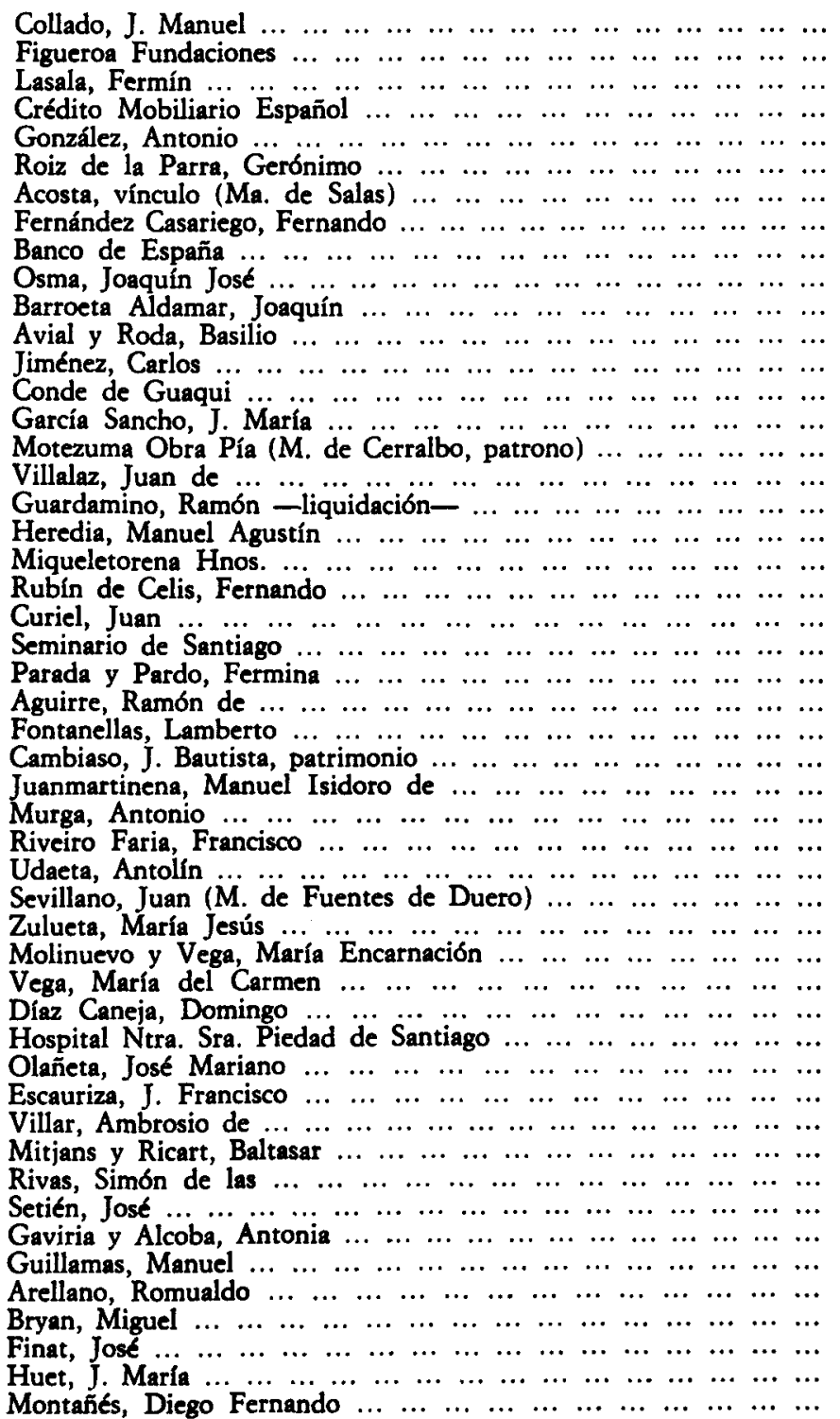 & 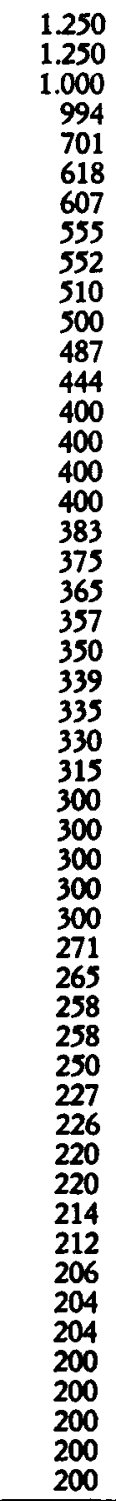 \\
\hline & & 19.952 \\
\hline
\end{tabular}

* De aquí en adelante ponemos entre paréntesis el título nobiliario del accionista. Nota: Figuran también, con 200 acciones, Torre y de la Hoz, Valverde y Zabalburu. 


\section{ANO 1871}

\begin{tabular}{|c|c|c|}
\hline$N .0$ & $T I T U L A R E S$ & Acclones \\
\hline $\begin{array}{l}1 \\
2 \\
3 \\
4 \\
5 \\
6 \\
7 \\
8 \\
9 \\
10 \\
11 \\
12 \\
13 \\
14 \\
15 \\
16 \\
17 \\
18 \\
19 \\
20 \\
21 \\
22 \\
23 \\
24 \\
25 \\
26 \\
27 \\
28 \\
29 \\
30 \\
31 \\
32 \\
33 \\
34 \\
35 \\
36 \\
37 \\
38 \\
39 \\
40 \\
41 \\
42 \\
43 \\
44 \\
45 \\
46 \\
47 \\
48 \\
49 \\
50\end{array}$ & 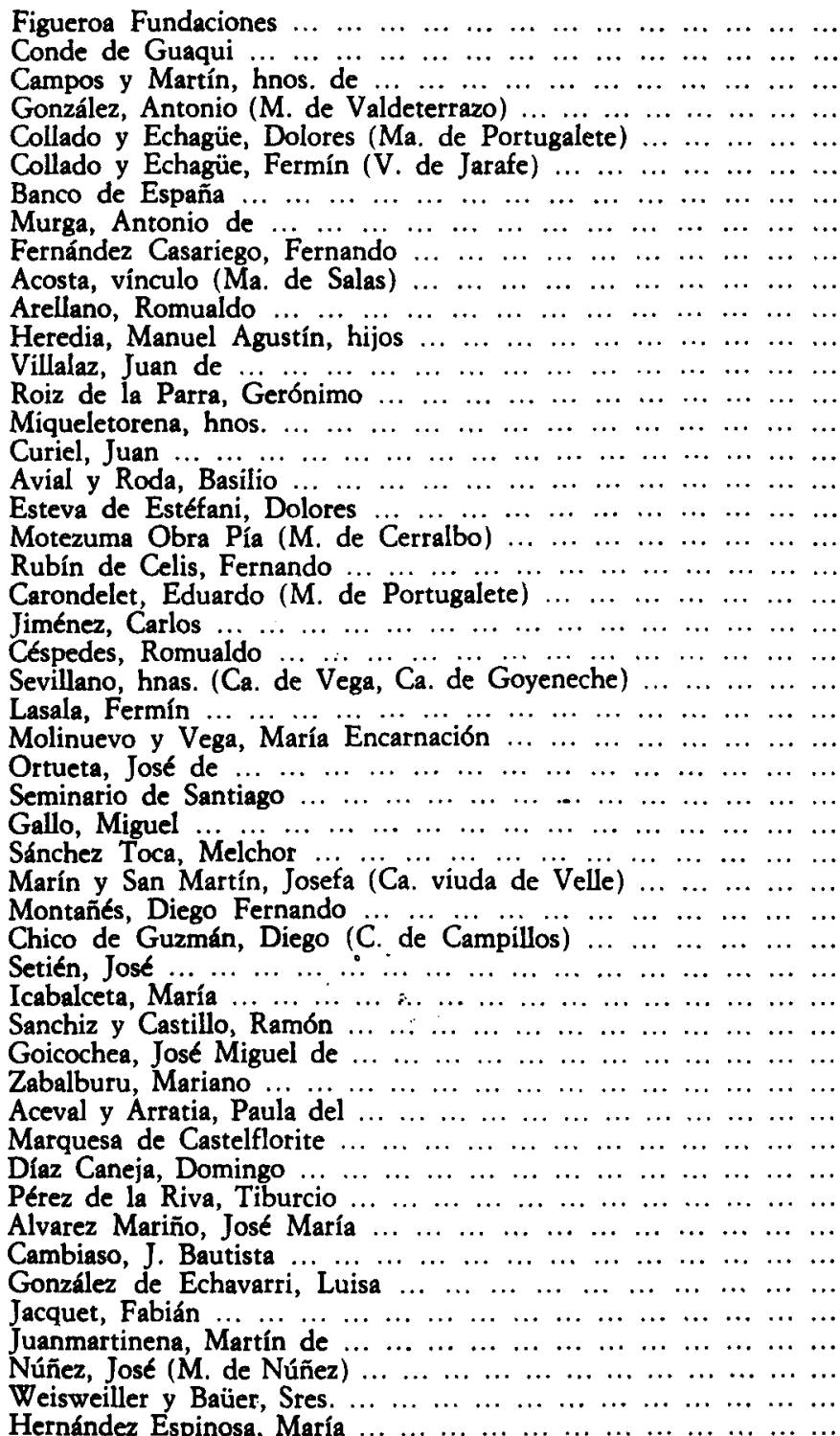 & $\begin{array}{l}1.563 \\
1.309 \\
1.186 \\
1.042 \\
1.041 \\
1.041 \\
810 \\
767 \\
750 \\
671 \\
660 \\
625 \\
600 \\
571 \\
569 \\
550 \\
500 \\
500 \\
500 \\
500 \\
471 \\
471 \\
466 \\
452 \\
450 \\
429 \\
428 \\
424 \\
400 \\
400 \\
387 \\
351 \\
350 \\
344 \\
340 \\
340 \\
334 \\
333 \\
332 \\
327 \\
312 \\
310 \\
300 \\
300 \\
300 \\
300 \\
300 \\
300 \\
300 \\
290\end{array}$ \\
\hline & & \\
\hline
\end{tabular}


ANO 1881

\begin{tabular}{|c|c|c|}
\hline N. ${ }^{\circ}$ & TITULARES & Acctones \\
\hline $\begin{array}{r}1 \\
2 \\
3 \\
4 \\
5 \\
6 \\
7 \\
8 \\
9 \\
10 \\
11 \\
12 \\
13 \\
14 \\
15 \\
16 \\
17 \\
18 \\
19 \\
20 \\
21 \\
22 \\
23 \\
24 \\
25 \\
26 \\
27 \\
28 \\
29 \\
30 \\
31 \\
32 \\
33 \\
34 \\
35 \\
36 \\
37 \\
38 \\
39 \\
40 \\
41 \\
42 \\
43 \\
44 \\
45 \\
46 \\
47 \\
48 \\
49 \\
50\end{array}$ & 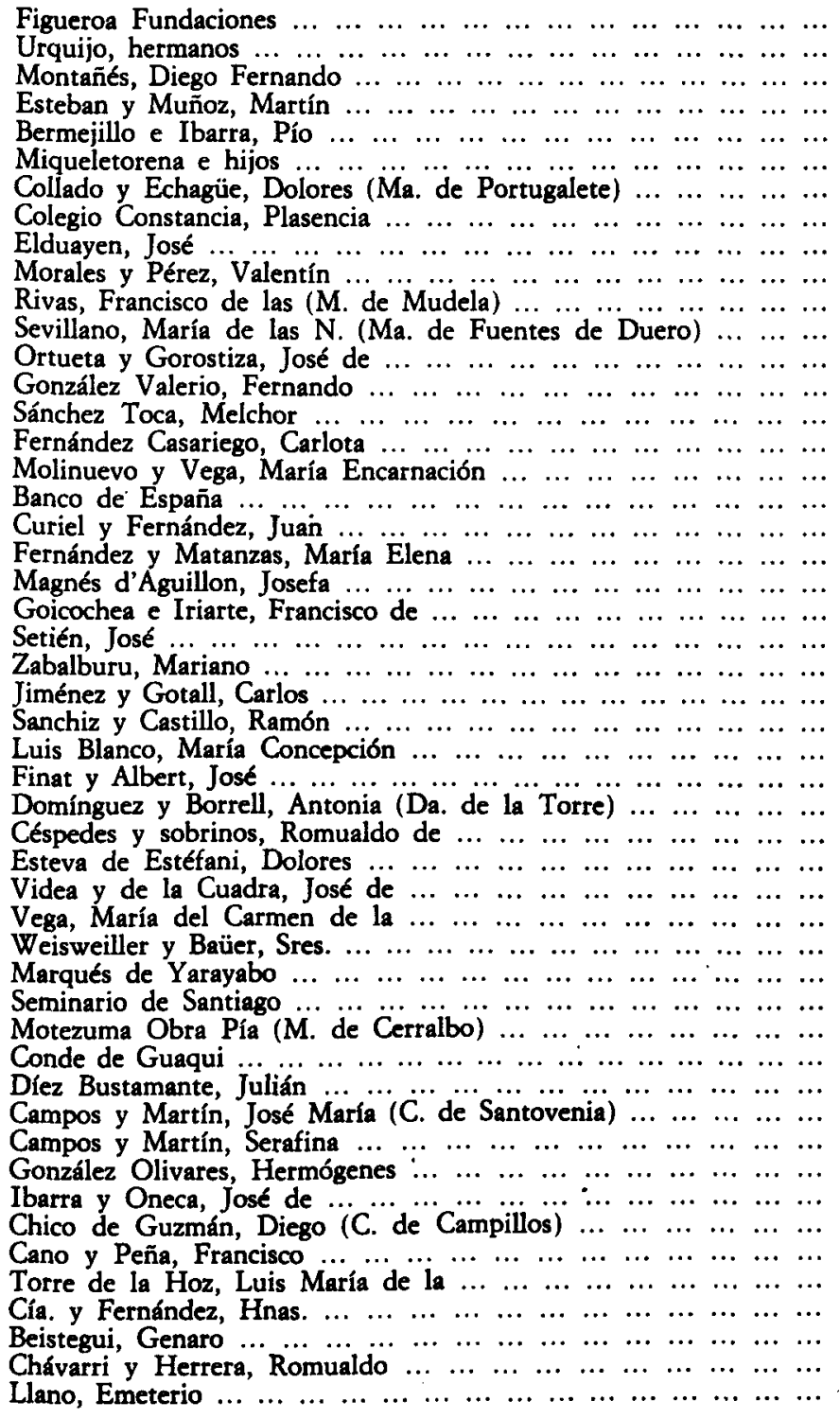 & $\begin{array}{r}1.719 \\
1.574 \\
1.558 \\
1.501 \\
1.361 \\
1.154 \\
1.011 \\
1.000 \\
1.000 \\
928 \\
883 \\
870 \\
836 \\
800 \\
770 \\
700 \\
688 \\
671 \\
650 \\
608 \\
581 \\
580 \\
577 \\
550 \\
538 \\
530 \\
527 \\
512 \\
509 \\
500 \\
500 \\
500 \\
496 \\
485 \\
480 \\
466 \\
450 \\
444 \\
440 \\
435 \\
435 \\
430 \\
415 \\
406 \\
400 \\
400 \\
397 \\
396 \\
396 \\
396\end{array}$ \\
\hline & & 34.453 \\
\hline
\end{tabular}


ANO 1891

\begin{tabular}{|c|c|c|}
\hline$N . .^{\circ}$ & $T I T U L A R E S$ & Acciones \\
\hline $\begin{array}{r}1 \\
2 \\
3 \\
4 \\
5 \\
6 \\
7 \\
8 \\
9 \\
10 \\
11 \\
12 \\
13 \\
14 \\
15 \\
16 \\
17 \\
18 \\
19 \\
20 \\
21 \\
22 \\
23 \\
24 \\
25 \\
26 \\
27 \\
28 \\
29 \\
30 \\
31 \\
32 \\
33 \\
34 \\
35 \\
36 \\
37 \\
38 \\
39 \\
40 \\
41 \\
42 \\
43 \\
44 \\
45 \\
46 \\
47 \\
48 \\
49 \\
50\end{array}$ & 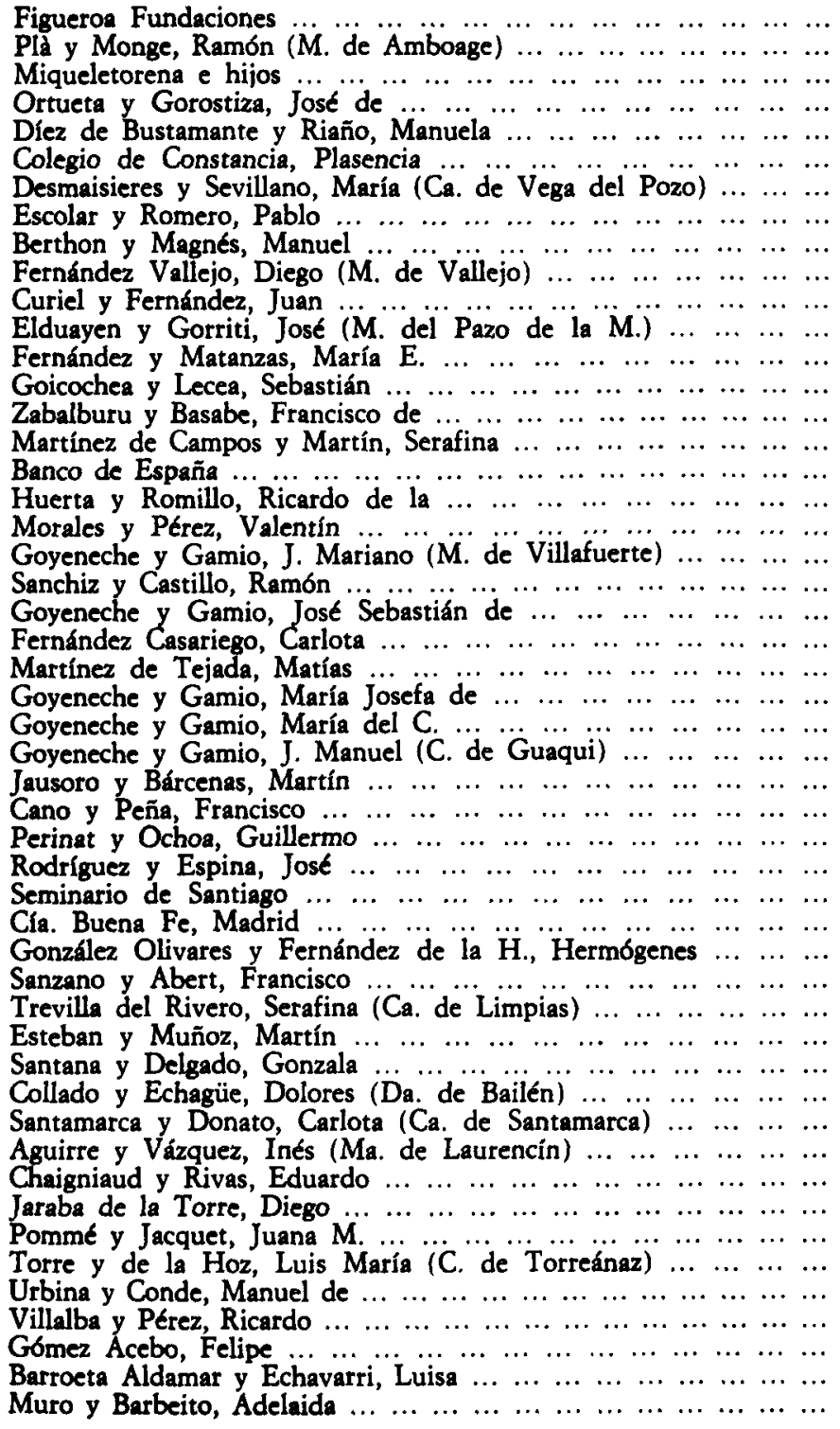 & $\begin{array}{l}2.577 \\
2.575 \\
1.980 \\
1.845 \\
1.800 \\
1.703 \\
1.400 \\
1.122 \\
1.064 \\
1.020 \\
1.000 \\
1.000 \\
912 \\
900 \\
880 \\
850 \\
831 \\
806 \\
800 \\
725 \\
707 \\
700 \\
682 \\
666 \\
650 \\
650 \\
639 \\
616 \\
600 \\
600 \\
593 \\
582 \\
577 \\
572 \\
570 \\
560 \\
557 \\
557 \\
551 \\
540 \\
511 \\
500 \\
500 \\
500 \\
500 \\
500 \\
500 \\
495 \\
468 \\
455\end{array}$ \\
\hline & & \\
\hline
\end{tabular}


ANO 1901

\begin{tabular}{|c|c|c|}
\hline$N .0$ & $T I T U L A R E S$ & Acclones \\
\hline $\begin{array}{r}1 \\
2 \\
3 \\
4 \\
5 \\
6 \\
7 \\
8 \\
9 \\
10 \\
11 \\
12 \\
13 \\
14 \\
15 \\
16 \\
17 \\
18 \\
19 \\
20 \\
21 \\
22 \\
23 \\
24 \\
25 \\
26 \\
27 \\
28 \\
29 \\
30 \\
31 \\
32 \\
33 \\
34 \\
35 \\
36 \\
37 \\
38 \\
39 \\
40 \\
41 \\
42 \\
43 \\
44 \\
45 \\
46 \\
47 \\
48 \\
49 \\
50\end{array}$ & 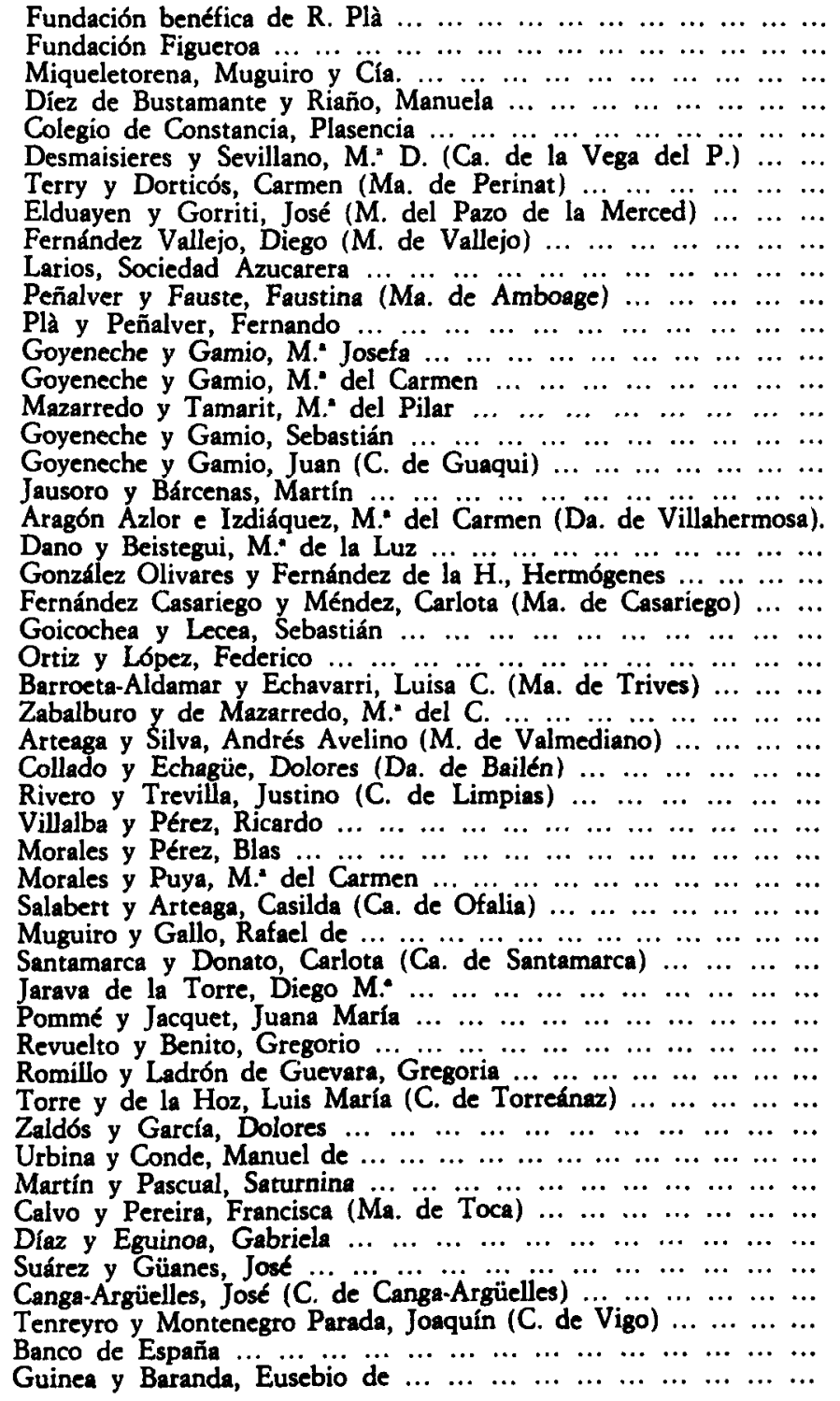 & $\begin{array}{r}3.823 \\
2.600 \\
2.359 \\
1.760 \\
1.703 \\
1.400 \\
1.056 \\
1.000 \\
950 \\
899 \\
866 \\
866 \\
850 \\
850 \\
826 \\
800 \\
770 \\
760 \\
735 \\
727 \\
716 \\
700 \\
683 \\
631 \\
620 \\
607 \\
600 \\
600 \\
600 \\
600 \\
570 \\
570 \\
562 \\
541 \\
540 \\
500 \\
500 \\
500 \\
500 \\
500 \\
500 \\
475 \\
470 \\
460 \\
457 \\
454 \\
442 \\
433 \\
425 \\
423\end{array}$ \\
\hline & & 41.779 \\
\hline
\end{tabular}


ANO 1911

\begin{tabular}{|c|c|c|}
\hline N.o & $T I T U L A R E S$ & Acciones \\
\hline $\begin{array}{l}1 \\
2 \\
3 \\
4 \\
5 \\
6 \\
7 \\
8 \\
9 \\
10 \\
11 \\
12 \\
13 \\
14 \\
15 \\
16 \\
17 \\
18 \\
19 \\
20 \\
21 \\
22 \\
23 \\
24 \\
25 \\
26 \\
27 \\
28 \\
29 \\
30 \\
31 \\
32 \\
33 \\
34 \\
35 \\
36 \\
37 \\
38 \\
39 \\
40 \\
41 \\
42 \\
43 \\
44 \\
45 \\
46 \\
47 \\
48 \\
49 \\
50\end{array}$ & 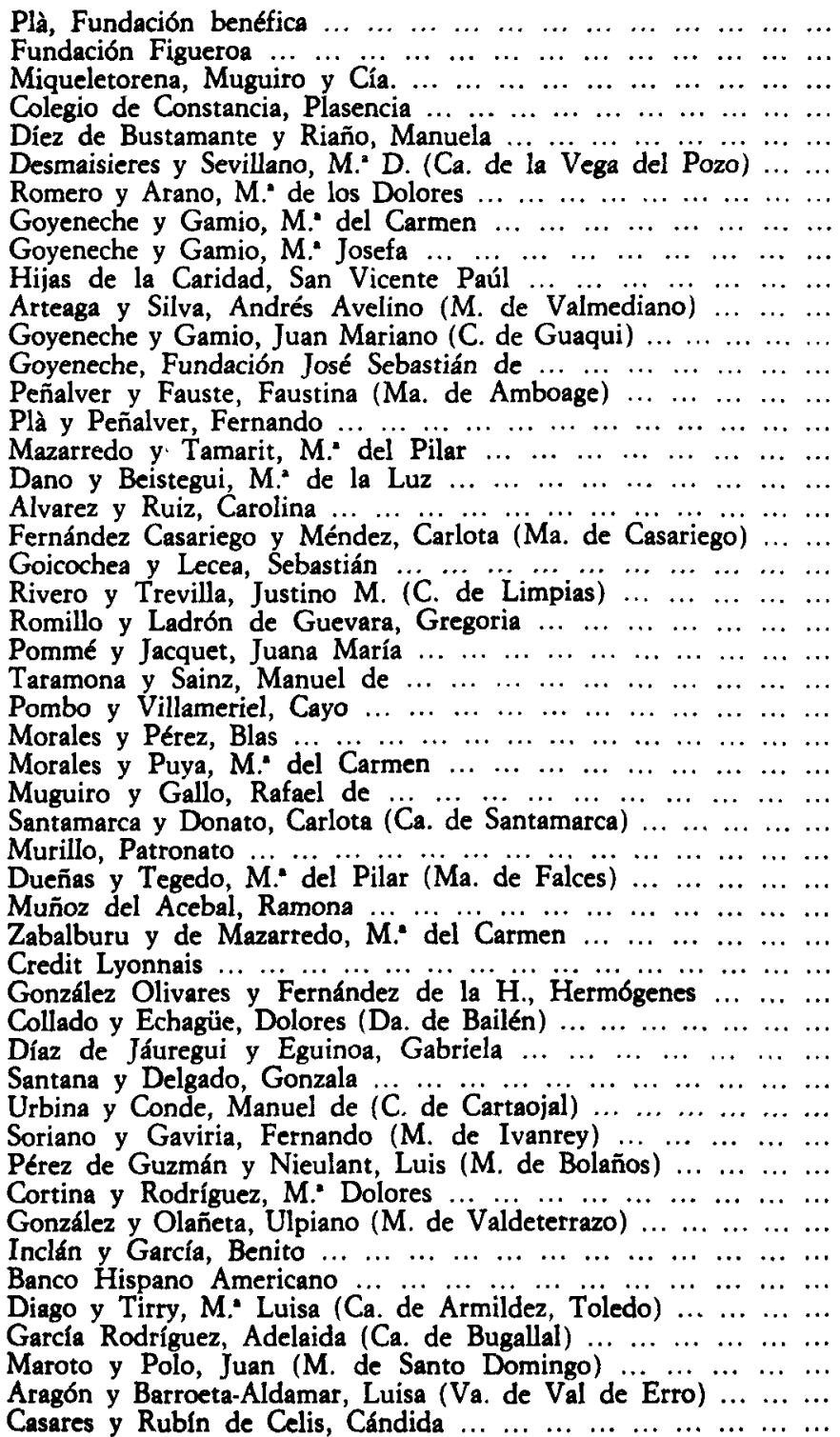 & $\begin{array}{l}3.823 \\
2.658 \\
2.065 \\
1.703 \\
1.450 \\
1.400 \\
1.400 \\
1.227 \\
1.210 \\
1.040 \\
970 \\
962 \\
907 \\
866 \\
866 \\
834 \\
727 \\
725 \\
700 \\
683 \\
668 \\
628 \\
600 \\
600 \\
590 \\
575 \\
570 \\
541 \\
540 \\
530 \\
511 \\
500 \\
500 \\
478 \\
478 \\
467 \\
457 \\
451 \\
425 \\
410 \\
406 \\
404 \\
402 \\
402 \\
402 \\
400 \\
400 \\
400 \\
384 \\
381\end{array}$ \\
\hline & & 40.711 \\
\hline
\end{tabular}


ANO 1921

\begin{tabular}{|c|c|c|}
\hline$N .9$ & TITULARES & Acciones \\
\hline $\begin{array}{r}1 \\
2 \\
3 \\
4 \\
5 \\
6 \\
7 \\
8 \\
9 \\
10 \\
11 \\
12 \\
13 \\
14 \\
15 \\
16 \\
17 \\
18 \\
19 \\
20 \\
21 \\
22 \\
23 \\
24 \\
25 \\
26 \\
27 \\
28 \\
29 \\
30 \\
31 \\
32 \\
33 \\
34 \\
35 \\
36 \\
37 \\
38 \\
39 \\
40 \\
41 \\
42 \\
43 \\
44 \\
45 \\
46 \\
47 \\
48 \\
49 \\
50\end{array}$ & 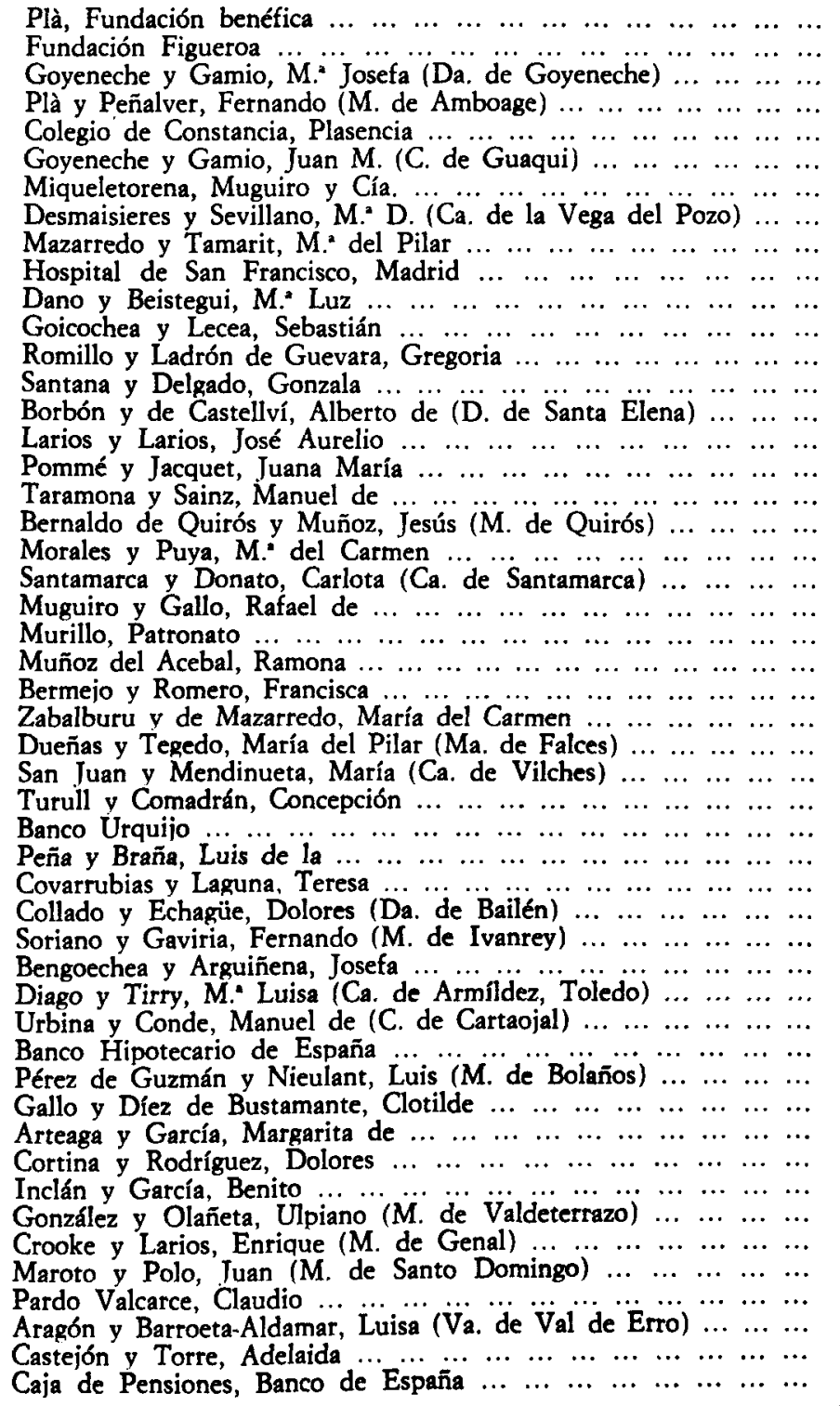 & $\begin{array}{l}3.823 \\
2.705 \\
1.824 \\
1.732 \\
1.703 \\
1.575 \\
1.477 \\
1.225 \\
834 \\
800 \\
730 \\
696 \\
650 \\
650 \\
600 \\
600 \\
600 \\
600 \\
588 \\
570 \\
552 \\
541 \\
530 \\
506 \\
500 \\
500 \\
476 \\
470 \\
470 \\
454 \\
451 \\
450 \\
430 \\
430 \\
426 \\
425 \\
425 \\
423 \\
420 \\
411 \\
408 \\
404 \\
402 \\
401 \\
400 \\
400 \\
400 \\
385 \\
377 \\
367\end{array}$ \\
\hline & & 37.046 \\
\hline
\end{tabular}


ANO 1931

\begin{tabular}{|c|c|c|}
\hline$N .{ }^{\circ}$ & TITULARES & Acclones \\
\hline $\begin{array}{r}1 \\
2 \\
3 \\
4 \\
5 \\
6 \\
7 \\
8 \\
9 \\
10 \\
11 \\
12 \\
13 \\
14 \\
15 \\
16 \\
17 \\
18 \\
19 \\
20 \\
21 \\
22 \\
23 \\
24 \\
25 \\
26 \\
27 \\
28 \\
29 \\
30 \\
31 \\
32 \\
33 \\
34 \\
35 \\
36 \\
37 \\
38 \\
39 \\
40 \\
41 \\
42 \\
43 \\
44 \\
45 \\
46 \\
47 \\
48 \\
49 \\
50\end{array}$ & 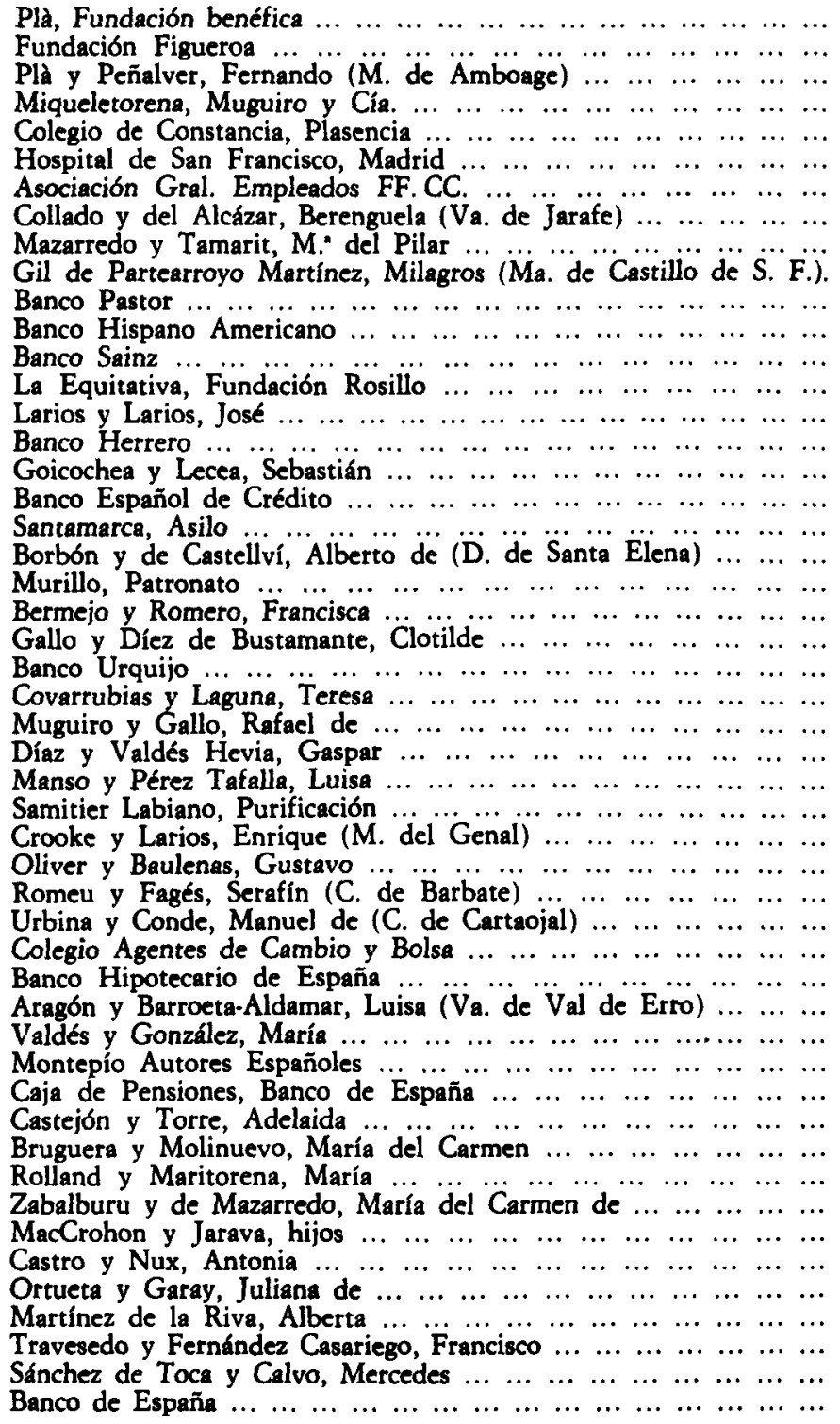 & $\begin{array}{l}3.823 \\
3.200 \\
2.047 \\
1.743 \\
1.703 \\
1.200 \\
1.150 \\
1.000 \\
1.000 \\
936 \\
908 \\
792 \\
734 \\
734 \\
734 \\
721 \\
703 \\
696 \\
673 \\
651 \\
636 \\
626 \\
590 \\
555 \\
554 \\
550 \\
541 \\
512\end{array}$ \\
\hline & & 38.989 \\
\hline
\end{tabular}




\section{SUCURSALES}

Accionistas que superan al número 50 de Madrid

(Número de acciones)

\begin{tabular}{|c|c|c|c|}
\hline & 1891 & 1901 & 1911 \\
\hline 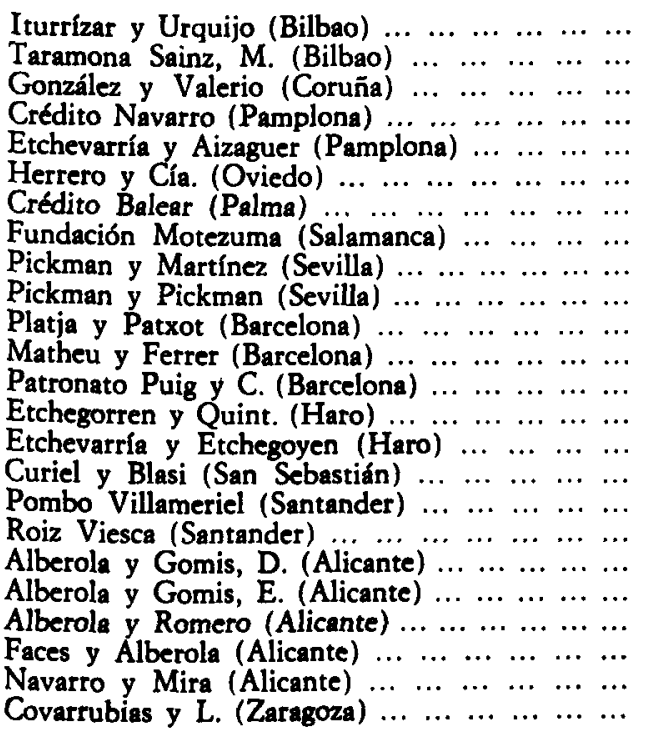 & $\begin{array}{r}661 \\
500 \\
786 \\
\overline{1.000} \\
610 \\
477 \\
675 \\
1.000 \\
= \\
= \\
= \\
= \\
= \\
= \\
= \\
= \\
=\end{array}$ & $\begin{array}{l}\overline{708} \\
\overline{-} \\
\overline{500} \\
\overline{675} \\
1.000 \\
\bar{Z} \\
\overline{8} \\
1.000 \\
\overline{1.150} \\
518 \\
431 \\
\overline{-} \\
= \\
=\end{array}$ & $\begin{array}{l}\overline{-} \\
\overline{7} \\
768 \\
\overline{501} \\
\overline{7} \\
\overline{754} \\
387 \\
450 \\
400 \\
800 \\
\overline{698} \\
\overline{-} \\
\overline{-} \\
600 \\
700 \\
800 \\
630 \\
800 \\
400\end{array}$ \\
\hline
\end{tabular}




\section{BIBLIOGRAFIA}

ANES, R. (1974): «El Banco de España (1874-1914): un Banco nacional», en La Banca española en la Restauración, Madrid, Banco de España, vol. I, pp. 107-215.

Anuario(s) Financiero y de Sociedades Anónimas de España, Madrid.

Atienza, I., y Mata, R. (1986): «La quiebra de la Casa de Osuna», Moneda y Crédito, 176, pp. 71-95.

BAHAmoNDE, A. (1981): El horizonte económico de la burguesía isabelina: Madrid, 18561866, Madrid, Univ. Complutense.

Bernis, F. (1921): El Banco de España y la economía nacional, Madrid.

Cámara de Comercio y Navegación de Barcelona (1920): Informe emitido en abril de 1919 sobre el proyecto de prórroga del privilegio de emisión del Banco de España, Barcelona.

Cámara de Comercio de Sabadell (1890): Dictamen acerca del proyecto de ley autori. zando al Banco de España para emitir basta mil millones de pesetas en billetes, Sabadell, Imp. Comas.

Ceballos, J. (1913): Nuestro problema monetario. Actuación y desarrollo del Banco de España, 2." ed., Madrid, Imp. Perales.

Congost, R. (1983): «La lista de los mayores contribuyentes de 1875», Agricultura y Sociedad, 27, pp. 289-375.

Elenco de Grandezas y Títulos nobiliarios españoles (1981), Madrid, Revista de Hidalguía.

Exposición del Ministerio de Hacienda, pidiendo a las Cortes aumentar contribuciones, usar de todos los fondos..., 5 septiembre 1837, Biblioteca Carandell, foll. 35.

Fontana, J. (1977): La Revolución liberal (Politica y Hacienda, 1833-1845), Madrid, IEF.

Galvarriato, J. A. (1921): El Banco de España. Sintesis de su labor, Madrid, Imp. Espinosa.

- (1923): El Banco de España. Momentos culminantes de su vida, Madrid, Imp. Espinosa.

García LÓPEZ, J. R. (1985): «Banqueros y comerciantes banqueros, clave oculta del funcionamiento del sistema bancario español del siglo xIX», Moneda y Crédito, 175, pp. $59-85$.

Guía oficial de Grandezas y Títulos del Reino (1977), Madrid, Ministerio de Justicia.

Hamilton, E. J. (1970): «El Banco Nacional de San Carlos (1782-1829)», en El Banco de España. Una bistoria económica, Madrid, Banco de España.

Mateo del Peral, D. (1974): «Aproximación a un estudio sociológico de las autoridades económicas en España (1868-1915)», en La Banca española..., vol. I, pp. 15-106.

JANKE, P. (1974): Mendizábal y la instauración de la monarquia constitucional (1790-1853), Madrid, Siglo XXI

Jiménez, J. M.' (1905): Estudio crítico de la crisis monetaria, Madrid, Est. Tip. de J. Ratés.

La Reforma del Banco de España (1902), Madrid, Imp. de A. Pérez.

Martínez PÉrez, E. (1922): Banco de España. Su régimen, operaciones y situación, 2." ed., Madrid, Gráficas Reunidas.

Martín ACEÑı, P. (1984): La politica monetaria en España, 1919-1935, Madrid, IEF.

- (1985): La cantidad de dinero en España, 1900-1935, Madrid, Banco de España.

Memoria(s) general(es) de la Junta de Accionistas del Banco de España.

Otazu, A. de (1987): Los Rotbschild y sus socios en España (1820-1850), Madrid, O. Hs. Ediciones.

Paret, L. V. (1921): «La nueva ley del Banco de España», Revista Nacional de Economí, XI, pp. 167-178.

Proyecto de ley por el que se reforma la de ordenación bancaria e informe del Banco de España (¿1931?), Madrid, Gráficas Reunidas.

Quarta Junta General del Banco Nacional de San Carlos celebrada en la casa del mismo Banco el día 29 de diciembre de 1785 (1786), Madrid, Imp. Vda. Ibarra, Hijos y Cía. 
Robledo, R. (1984): «Desamortización y Hacienda Pública en algunos inventarios de grandes terratenientes", en A. García Sanz y R. Garrabou, Historia agraria de la España Contemporánea, I, Barcelona, Crítica, pp. 395-432.

- (1985): Notas sobre el papel de las grandes fortunas en la España contemporánea (Memoria inédita), Banco de España.

RodRíGUEz, L. (1902): La actual crisis financiera. Historia maldita, Madrid, Est. Tip. de A. Marzo.

RuBinsteIN, W. D. (1981): "New men of wealth and the purchase of land in nineteenthcentury Britain», Past and Present, 92.

SÁNCHEZ DE TOCA, J. (s. f.): Los Bancos de Emisión y la política económica de la guerra moderna, Madrid, Imp. J. Ratés.

Santillán, R. de (1865): Memoria bistórica sobre los Bancos Nacional de San Carlos, Español de San Fernando, Isabel II, Nuevo de San Fernando y de España, Madrid, Est. Tip. T. Fortanet.

TAlladA, J. M." (1946): Historia de las finanzas españolas en el siglo XIX, Madrid, Espasa-Calpe.

TEDDE, P. (1974): «La banca privada española durante la Restauración (1874-1914)», en La Banca española..., vol. I, pp. 217-455.

- (1983): "Comerciantes y banqueros madrileños al final del Antiguo Régimen», en Historia económica y pensamiento social, Madrid, Alianza-Banco de España.

Tortella, G. (1970 a): «La evolución del sistema financiero español de 1856 a 1868», en Ensayos sobre la economía española a mediados del siglo XIX, Madrid, Ariel.

- (1970 b): «El Banco de España entre 1829 y 1929», en El Banco de España. Una bistoria económica, Madrid, Banco de España.

- (1972): Los orígenes del capitalismo en España, Madrid, Tecnos.

Tortella, T. (1986): Indice de los primitivos accionistas del Banco de San Carlos, Madrid, Banco de España. 